\title{
An integrated landscape management approach to sustainable bioenergy production
}

Shyam K. Nair, Damon S. Hartley, Tessica A. Gardner, Gabe McNunn, Erin M. Searcy

September 2017

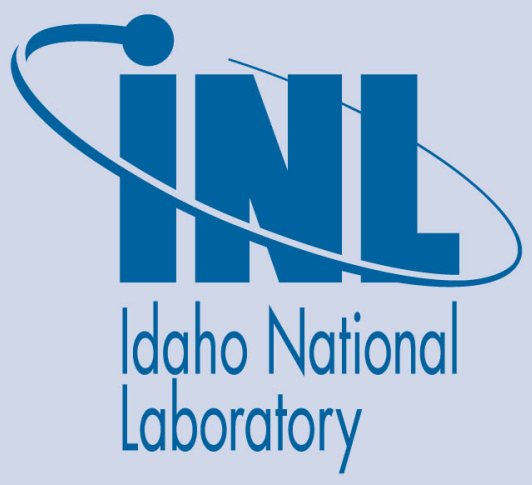

The INL is a U.S. Department of Energy National Laboratory operated by Battelle Energy Alliance 


\title{
An integrated landscape management approach to sustainable bioenergy production
}

\author{
Shyam K. Nair, Damon S. Hartley, Tessica A. Gardner, Gabe McNunn, Erin M. \\ Searcy
}

September 2017

Idaho National Laboratory Idaho Falls, Idaho 83415

http://www.inl.gov

Prepared for the U.S. Department of Energy

Office of Energy Efficiency and Renewable Energy

Under DOE Idaho Operations Office

Contract DE-AC07-05ID14517 
$3 \quad{ }^{*}$ Bioenergy Technologies, Clean Energy and Transportation Science \& Technology, EES\&T Division, Idaho

$4 \quad$ National Laboratory, Idaho Falls, ID 83415, USA.

$5 \quad$ AgSolver, 2701 Kent Ave, Suite 130, Ames, IA 50010, USA.

6 Corresponding author: Shyam K. Nair, shyam.nair@inl.gov, phone: (208) 526-3071, fax: (208) 526-3150 


\section{Abstract}

Integrated landscape management has emerged in recent years as a methodology to integrate the environmental impacts of various agricultural practices along with yield and profitability in a variety of cropping systems. In this study, the Landscape Environmental Assessment Framework (LEAF), a decision support toolset for use in integrated landscape management and developed at Idaho National Laboratory, was used to evaluate the profitability of grain producing subfields, to determine the efficacy of sustainably harvesting residual biomass after grain harvest, and to determine the efficacy of integrating bioenergy crops into grain-producing landscapes to enhance farmer profitability. Three bioenergy crops, sorghum, switchgrass, and miscanthus, were integrated into non-profitable subfields in four U.S. counties. The manuscript describes in detail the material and methods used to define crop rotations, land management units and practices, subfield units and productivity, grain profitability, sustainability criteria, energy crop integration, and feedstock cost estimation. With the integration of bioenergy crops, the overall annual biomass production rates in the four counties could be increased by factors ranging from 0.8 to 21 , depending on the energy crop and county, over the annual residue biomass production rates. By modeling the harvesting of residual biomass and energy crops using geo-referenced, precision harvesting equipment and optimal harvesting paths on individual sub-fields, the average logistics costs including harvesting of both residual biomass and energy crops were observed to fall well below US DOE's 2017 goals for biomass feedstock price of US $\$ 84 /$ ton or US\$92.6/dry Mg. Miscanthus, grown in counties in Ohio and Kansas, provided the maximum potential, among the three energy crops considered, for increment in biomass production and also posed maximum threat to the grain production. Considerable variability was observed in the harvesting and total costs because of the size, shape, and productivity of individual subfields. It was shown that variability in the harvesting costs could be used to down-select non-profitable farms with low harvesting costs and high residue and bioenergy crop yields and to reduce the negative impacts of bioenergy crop integration into croplands on grain production. The results of the assessment suggest that (1) the potential to produce biomass is considerably enhanced when non-profitable grain-producing subfields are replaced by bioenergy crops, (2) the subfield-scale integrated landscape assessment provides a defensible methodology to directly address individual farmer's profitability, sustainability, and environmental stewardship.

\section{Keywords}

Landscape Environmental Assessment Framework, LEAF, biomass, energy crops, switchgrass, miscanthus, feedstock, herbaceous biomass, logistics cost, bioenergy 


\section{Introduction}

42 Research on increasing production of lignocellulosic biomass in the US gained momentum after the US Government 43 passed the Energy Independence and Security Act in 2007, which set a requirement of 60.5 million $\mathrm{m}^{3}$ (16 billion 44 gal) of cellulosic biofuel production by 2022 [1]. Bioenergy Technologies Office (BETO) of US Department of 45 Energy's Office of Energy Efficiency and Renewable Energy has since set an operational goal for the US bioenergy industry of 222 million Mg (245 million tons) of biomass/y by 2017 and a goal of 259 million $\mathrm{Mg}$ (285 million tons) of biomass/y by 2022 utilizing a diversity of biomass resources at a feedstock delivery cost of US $\$ 92.6 / \mathrm{dry} \mathrm{Mg}$ (US\$84/ton) or lower in $2014 \$$ [2]. The bioenergy researchers are focusing on agricultural-herbaceous and forestrywoody sources to rapidly build up the lignocellulosic feedstock capacity. Low-value sawmill discards and wood chips from the forest industry represent the woody biomass. Low-value waste products or post-grain harvest residues from agriculture such as corn stover and sugarcane bagasse represent the herbaceous biomass along with energy crops such as switch grass, miscanthus, and willow. Energy crops have been proposed as a means to supplement emerging supplies of agricultural residues to sustainably attain the BETO goals while also reducing land use requirements [3]. However, extensive research and analysis are required to avoid unintended consequences to the environment and to establish the economic advantages to biomass producers and the bioenergy market [4]. Excessive harvesting of plant residues results in the removal of vegetative protection over the soil substrate. Large fractions of soils are then exposed to wind and precipitation-driven erosive forces which remove both soil and chemical resources such as carbon and nutrients from agricultural lands, reducing the year-to-year sustainability of agriculture. Wind-driven emissions of carbon and volatilization of nutrients result in increased GHG loading of the atmosphere. Sediment and chemical losses to runoff result in increased loading of surface water bodies and excessive nutrient concentrations in the waters result in highly productive water systems leading to algal bloom and hypoxic water conditions killing valuable ecosystem components and reducing ecosystem services. These unintended consequences can easily offset benefits in terms of the amounts of residue feedstock produced and result in long-term adverse socioeconomic impacts. Recent research through modeling studies, however, have shown that it is possible to sustainably remove agricultural residue by limiting the removal of residues using soil and soilcarbon erosion criteria [5-8]. Sustainability in this context refers to the year-to-year continuation of grain and rowcrop agriculture with minimal addition of soil carbon and nutrients each year. Energy crops such as energy sorghum, switchgrass, willow, sugarcane, energycane, napier grass, and miscanthus have emerged in recent years as alternative biomass to plant residues, with high yields even on marginal lands and high potential to meet BETO's feedstock production goals [3, 9 - 15]. Most of these (except sorghum in the US) also

71 have the advantage of being perennial species and some of them have multi-year harvest cycles. There are also other

72 advantages of growing perennial bioenergy crops instead of row crops - reductions in greenhouse gas emissions and 73 agricultural pollution per hectare [16-19]; increased biodiversity and ability to restore contaminated lands [20-22];

74 fossil carbon substitution and reduction in $\mathrm{CO}_{2}$ emissions [23]; provision of ecosystem services such as reduced 75 nutrient runoff, reduced erosion, carbon sequestration, and wildlife habitat [15, 24-25]; ability to grow on marginal 76 lands under different geographies and environments with high yields from low inputs [26, 27]; and providing high 
77 water and nitrogen use efficiencies with cold-climate adaptation and less annual establishment requirements [15, 78 26].

79 Off-target nutrient runoff from fertilizer applications has been identified in recent years as a major anthropogenic

80 contributor to aquatic, estuarine, and marine ecosystem nitrification, potentially leading to their over-enrichment;

81 nuisance blooms of opportunistic bacteria, cyanobacteria, and algae; and hypoxia or depletion of dissolved oxygen

82 [28-36]. Because of the ability to sequester carbon and soil and capture nutrients from runoffs off agricultural lands,

83 bioenergy crops have been recommended as an effective means to improve surface water quality and ecosystem

84 services as well as improve farmer's capacity to generate water quality credits that can be bought by industry to

85 offset their environmental permitting requirements [37-42].

86 Sustainable and responsible bioenergy production has therefore become a central theme to avoid adding additional

87 environmental burden to future generations. BETO has the goal that at least one biofuel technology will be

88 identified that reduces GHG emissions by $50 \%$ or more compared to petroleum fuels and meets targets for water use, wastewater and air emissions while getting the price below \$3/gasoline gallon equivalent (GGE) [2]. BETO would also like to identify landscape design approaches of at least two bioenergy systems by 2022 that can improve land-use efficiency and maintain ecosystem and social benefits and evaluate environmental and socioeconomic indicators across the supply chain for three cellulosic and algal bioenergy systems to validate the environmental emission targets and socio economic benefits [2].

94 Farmers are protected through federal crop insurance programs against losses on grain production. Many farmers grow row crops assuming a price upswing and buy crop insurance to minimize loss. However, programs like the Biomass Crop Assistance Program (BCAP) [43], provide incentives for growers to switch to new crops. Through participation in the BCAP program, crops are grown that could be used by biorefineries. The incentive of a ready market may lead to producers more willing to grow them. Another incentive for farmers to grow energy crops is the ability of these crops to consume less water and nutrients. In the Midwestern states, the water table in the Ogallala Aquifer has been steadily declining to the extent that the farmland prices on the fringes of the aquifer have dropped significantly in the past 10 years.

102 Questions that are important to sustaining agriculture while ensuring the retention or enhancement of ecosystem services $([44,45]$ are also pertinent to decisions on residue harvesting because amount of soil erosion and carbon and nutrient removal by wind and water are directly dependent on and in proportion to the amount of biomass

105 harvested as residues. On the other hand, strategically switching to energy crops in select landscape locations could 106 preserve nutrients, carbon, and soil within the landscape ([46, 39]. Several recent modeling studies at the subfield 107 (subfield is a subsection of a farmer's field or Common Land Unit, CLU, that is differentiable by soil type or other surface characteristics) and landscape levels have also shown that it is possible to sustainably remove agricultural residue $([5,6,8,47,48]$.

110 For the agriculture-based bioenergy production to even take-off, it is essential to establish long-term profitability of

111 farmer and minimize the nutrient and carbon losses at the farmer level. Hence, the focus of this study is the 112 profitability and environmental sustainability at the farmer level using a landscape approach to evaluate multiple 
113 subfields of various sizes. Opportunities to harvest plant residue on grain or row crop fields in the US were

114 investigated along with opportunities to grow energy crops on non-profitable fields.

116 Materials and Methods

117 Four counties in four U.S. states with over $90 \%$ of agriculture area devoted to corn production were randomly

118 selected for analysis using available data from 2010 to 2014 to show how subfield profitability could be used as a

119 driver to (1) encourage environmentally sustainable production of biomass for bioenergy and (2) enhance total

120 biomass production with the introduction of energy crops on non-profitable subfields at a low cost to the

121 farmer/grower. The methodology used the Landscape Environmental Assessment Framework (LEAF), originally

122 developed at the Idaho National Laboratory [8], and built upon past efforts ([6, 47]) at sub-field resolution to explore

123 opportunities for biomass production from grain residue and energy crops. Bonner et al. [6, 48] investigated the

124 feasibility of growing energy crops on subfields in Hardin County, Iowa, extended the analysis to Gerro Gardo

125 County in Iowa, and applied multi-criteria decision analysis to show that subfield productivity, profitability, and

126 environmental performance can all be improved simultaneously by identifying management areas for switchgrass

127 production and stover harvest. The analysis presented here focused on predominantly corn-producing counties in the

128 four states; and, different energy crops were assumed to be grown in these counties according to prevailing climates

129 and soil. The energy crops considered include sorghum, lowland switchgrass, and miscanthus. Sorghum is an annual

130 energy crop, which produces large amounts of biomass in semi-arid environments with reduced susceptibility to

131 abiotic stresses including drought [49]; hence, it was used as the preferred energy crop for Texas. Miscanthus and

132 switchgrass are perennial, thin-stemmed herbaceous $\mathrm{C} 4$ plants that produce high dry matter yields and are suitable

133 with many crop production systems $[47,50]$ and it was decided to use switchgrass in Tennessee and miscanthus in

134 Kansas and Ohio. The methods developed for integrated landscape modeling were directly applicable to Tennessee

135 and Ohio counties with little to no modification; for counties in Kansas and Texas, limitations in data quality,

136 availability, and/or applicability required additional assumptions regarding landscape productivity, management

137 boundaries, and profitability. Harvest of residual biomass was constrained by sustainability criteria to ensure year-

138 to-year availability of organic matter and soil for sustained multi-year production of grains and biomass. Production

139 of residual biomass and energy crops involve additional logistics costs, to be estimated at CLU level (representing a

140 farmer or grower), for harvesting, baling, preprocessing, handling, and transportation. This section is organized in

141 accordance with the main components of the analysis, including: crop rotations, land management units and

142 practices, subfield units and productivity, profitability, biomass availability, and environmental impacts.

143 Crop Rotations

144 Land cover was determined using the Cropland Data Layer (CDL) for each year from 2010 to 2014, creating a five-

145 year rotation for each field within the four counties. Table 1 lists the crops used to form rotations and the relative

146 area of corn-producing land captured by the cover selections. Instances of less than $100 \%$ indicated that some other

147 cover type (e.g., another field crop or non-crop cover) occurred on a corn-producing field within the 5-year span.

148 Such fields are therefore not captured in downstream analyses. 


\section{Land Management Units \& Practices}

150 Field boundaries based on the 2008 CLU data were successfully applied to each of the counties with the exception 151 of Castro County, TX. A key component of the analysis methodology is assigning real-world crop rotations to actual 152 management units. As noted in the previous section, crop rotations are determined from the CDL which is based on 153 remotely sensed ground cover data. Rotations are then assigned to CLU boundaries on a majority-cover basis. In the 154 case of Castro County, the CLU boundaries encompass numerous management units, as illustrated in Fig 1 (left), 155 where six center pivots are classified by a single CLU. In this instance, the crop on each pivot, plus the cover in the 156 pivot-corners, would be considered and a majority cover would be assigned to the CLU level. Not only would this

157 be a simple misclassification, but would result in downstream inaccuracies in crop area calculations and thus crop 158 yields. To overcome this challenge, the CDL data was used to create new management boundaries based on the 159 shapes formed by contiguous pixels with matching crop cover. The resulting shapes resemble the reality of pivot 160 irrigated fields more closely than the CLU boundaries (Fig. 1, right).

Table 1 Crops used in forming five year rotations for each county and the relative area of corn producing fields captured.

\begin{tabular}{ccc}
\hline County & Crops/Cover in Rotation & $\begin{array}{c}\text { \% of Corn Acres } \\
\text { Captured }\end{array}$ \\
\hline Castro, TX & Corn, Winter Wheat, Cotton, Sorghum, Pasture & $100 \%$ \\
Dyer, TN & Corn, Soybean, Winter Wheat, Cotton & $90 \%$ \\
Hancock, OH & Corn, Soybean, Winter Wheat & $96 \%$ \\
Sheridan, KS & Corn, Soybean, Winter Wheat, Sorghum, Fallow & $94 \%$ \\
\hline
\end{tabular}

161 The fields selected for analysis in each of the four counties are shown in Fig. 2. Management practices for each 162 county were built from the base management templates within RUSLE2 ([51], part of LEAF) for all combinations of 163 crop rotations achievable from Table 1. The NRCS Crop Management Zone (CMZ) [52], tillage intensity, and 164 energy crop used for modeling each county is presented in Table 2. Management practices were modified based on 165 verbal communication with NCRS district conservationists and university agronomic guidelines to resemble the 166 most common management practiced within each county.

167 Table 2 Management zones, tillage practices, and energy crops used for modeling management practices of each 168 county.

\begin{tabular}{cccc}
\hline County & $\begin{array}{c}\text { Crop Management } \\
\text { Zone }\end{array}$ & $\begin{array}{c}\text { Row Crop Tillage } \\
\text { Practice }\end{array}$ & Energy Crop \\
\hline Castro, TX & 19 & Reduced Till & Sorghum \\
Dyer, TN & 63 & Reduced Till & Lowland Switchgrass \\
Hancock, OH & 16 & Reduced Till & Miscanthus \\
Sheridan, KS & 5 & No Till & Miscanthus \\
\hline
\end{tabular}


171 SSURGO soil map unit boundaries were used to create subfield units for each county by intersecting the soil data

172 with field boundaries. The productivity of these soil units within each subfield must be estimated for the crop type

173 determined to be produced. Hancock County was the only instance where a soil-based yield estimate in bu/ac was

174 available for corn, soybean, and wheat (Table 3). The final validation associated with estimating subfield

175 productivity is a reliable estimate of county-level annual crop production. In most cases, the NASS production

176 statistics satisfy this need, but in some instances there were no reported data for one or more years from 2010 to

177 2014, or the data that were reported were of poor quality or misleading. Sheridan and Castro counties faced

178 challenges in production data availability or quality, resulting in the implementation of additional specialized

179 assumptions.

180

181

182

183

184

185

186

187

188

189

190

191

192

193

194

195

196

197

198

199

200

201

202

203

204

The SSURGO predicted yields were normalized to the National Agricultural Statistics Service (NASS) annual production values for each crop and year. This is done by first calculating the county level estimated grain production across all soil types in a given year:

$$
E Y_{j x}=\sum_{i} a_{i j x} \cdot \operatorname{SSURGO}_{i x}
$$

where $\mathrm{EY}_{\mathrm{jx}}$ is the estimated county level yield in year $j$ for crop $x, \mathrm{a}_{\mathrm{jjx}}$ is the area of a given soil map unit $i$ in year $j$ producing crop $x$ and $\mathrm{SSURGO}_{\mathrm{ix}}$ is the estimated yield for soil $i$ and crop $x$. A correction factor can then be determined for each year and crop:

$$
C F_{j x}=\left(N Y_{j x}-E Y_{j x}\right) / N Y_{j x}
$$

where $\mathrm{CF}_{\mathrm{jx}}$ is the annual correction factor for year $j$ and crop $x$ and $\mathrm{NY}_{\mathrm{jx}}$ is the NASS reported county level corn grain production for year $j$ and crop $x$. This technique maintained realistic county-level production of each crop, but distributed production across the Hancock County landscape in such a way that variation in subfield conditions were respected, resulting in non-uniform crop production within each field. For the remaining counties, a soil-based estimate of yield was not available and the National Commodity Crop Productivity Index (NCCPI) was evaluated as an alternative method for generating subfield yields and variability. To improve the index's ability to provide reasonable subfield crop yields, the following transformation was developed:

Transformed NCCPI $=\left\{\begin{array}{c}0.25 \text { for NCCPI }<0.3265 \\ {[2-\sqrt{1 / N C C P I}] \text { for NCCPI } \geq 0.3265}\end{array}\right.$

The NCCPI score for each soil can then be used to generate a correction factor for estimating crop yields by substituting $\mathrm{SSURGO}_{\mathrm{ix}}$ in equation 1 with an NCCPI score:

$$
E Y_{j}=\sum_{i} a_{i j} \cdot \mathrm{NCCPI}_{i}
$$


where $\mathrm{NCCPI}_{\mathrm{i}}$ is the index score for soil $i$ and the subscript $x$ drops from each variable because there is not a cropspecific index score. Equation 2 was then adhered to, generating a correction factor that when multiplied by the soil specific index score returned a subfield crop yield.

This method of subfield productivity failed in Castro County. Because the NCCPI was developed for dryland farming and Castro County was reliant on irrigation, many of the soils within study fields had NCCPI scores less than the 0.3265 requirement set in equation 3 . When the transformation was applied, a large portion of fields were adjusted to a fixed rate of 0.25 . In this case, the non-transformed NCCPI scores were used to create county level

212 adjustment factors.

213 Table 3 Source of subfield yield information for each county and subsequent processing.

\begin{tabular}{|c|c|c|}
\hline County & $\begin{array}{c}\text { Source of Subfield } \\
\text { Variability }\end{array}$ & Additional Processing \\
\hline Castro, TX & NCCPI & $\begin{array}{cl}\text { - } & \text { Balanced to NASS production (Eq 2) } \\
\circ & \text { Manual adjustment of Cotton } \\
\circ & \text { Manual adjustment of Sorghum } \\
\circ & \text { Manual adjustment of Wheat }\end{array}$ \\
\hline Dyer, TN & NCCPI & $\begin{array}{ll}- & \text { Transformed }(\mathrm{Eq} 3) \\
- & \text { Balanced to NASS production }(\mathrm{Eq} 2)\end{array}$ \\
\hline Hancock, OH & SSURGO bu/ac yield & - $\quad$ Balanced to NASS production (Eq 2) \\
\hline Sheridan, KS & NCCPI & 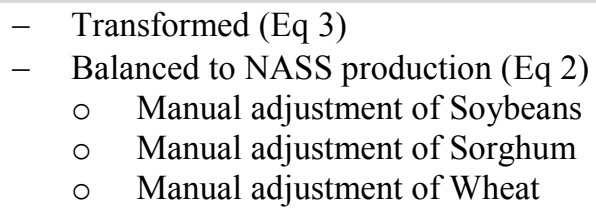 \\
\hline
\end{tabular}

215 In the case of Castro County, the CDL-raster was used to generate zonal statistics to the SSURGO polygons for 216 acreage of each crop in each year. This provided reasonable results for all crops but cotton. Dryland cotton had been 217 heavily damaged by drought in northern Texas for the past several years, resulting in widespread stand failure. For 218 example, NASS reports 80,000 acres of cotton being planted in 2011 [53], but only 45,000 acres being harvested.

219 No data source exists to inform what fields were harvested, and which were lost. As a result, all cotton producing 220 areas would be assigned an artificially low yield to spread the burden of widespread stand failure. Because the 221 failure was primarily due to drought, it was decided to use the custom field boundaries described earlier for acreage 222 determination for cotton, as these polygons primarily represent irrigated fields. By doing this, the acreage estimation 223 for cotton was slightly lower than harvested area reported by NASS [53] and the resulting correction factors resulted 224 in yield estimates that were likely higher than reality, but this was a much safer assumption than slashing all fields 225 due to dryland crop failure.

226 Also for Castro County, the NASS data for wheat and sorghum were extremely limited and poor. Data on the area of 227 land that was harvested, and yields, were very inconsistent and appear incomplete, resulting in unreasonable 228 correction factors and extremely low yields. In lieu of sufficient data, the yield for wheat and sorghum were 229 generalized to match an average yield of $60 \mathrm{bu} / \mathrm{ac}$ for wheat and $55 \mathrm{bu} / \mathrm{ac}$ for sorghum when projected onto the 
distribution of NCCPI by acres within the fields of interest. This resulted in a correction factor of 137.3 for wheat and 125.9 for sorghum that was then multiplied by NCCPI to determine a yield estimate for all years.

232 Sheridan County had multiple gaps in the annual NASS yield data. In the case of soybeans, an annual yield was only 233 reported for 2012. As a result, the correction factor for that single year was applied to all five years of modeling.

234 Sorghum yields were not available for 2011, 2013, and 2014, so the average of the 2010 and 2012 correction factors

235 was applied to these three years. Finally, the 2013 winter wheat yield was missing, so the average of the other four

236 year's correction factors was applied to this year.

\section{Profitability}

238 Estimation of subfield profitability is critical for judging the opportunity for energy crops to be integrated into a

239 landscape. There are two major components to this step: (1) operating costs and returns of crop management and

240 production, and (2) estimation of land rental rates. The yield estimates for crops produced in each county were used

241 in conjunction with University enterprise budgets for local crop production to determine annual net profit (Table 4).

242 Commodity prices used for each of the budgets are shown in Table 5. Profitability is expected to be highly sensitive

243 to crop price, so while the values in Table 5 were derived from national average commodity prices from 2010 to

2442014 , the importance of these costs on the outcomes of the analyses should not be overlooked.

245 Land rent is an important component of the fixed costs of crop production. In practice, unique parcels have rental

246 rates that are determined based on the productivity and value of the land, such that highly productive fields

247 command a premium, while low yielding fields may come with a lower rental rate. Unfortunately, data were not

248 available to determine the specific value of all agricultural fields, and generalized assumptions had to be made. In

249 the case of Hancock, OH, university rental surveys were associated with the productivity of agricultural operations.

250 This allowed a more mature estimate of rental rates to be estimated based on the productivity of any given

251 management unit within the county. The remaining four counties however did not provide such detailed information,

252 and instead only a county-level rent was available and was generalized to all fields within the county, regardless of

253 differences in productivity (Table 6). Though this assumption was overly simplistic and likely over-represented the

254 value of unproductive fields and under-represented the value of highly productive fields, the generalization

255 nevertheless allowed for simple, high-level insights regarding profitability to be made. Sensitivity analysis methods,

256 out of the scope of this study, can be applied to determine the sensitivity of profitability to crop price, rent, yields,

257 and area.

258 Table 4 Source of crop budgets used to calculate production costs and profit for each county.

\begin{tabular}{|c|c|}
\hline County & Crop Budget Source \\
\hline Castro, TX & $\begin{array}{c}\text { Texas A\&M AgriLife Extension Agricultural Economics } 2015 \text { District } 2 \text { Texas } \\
\text { Crop and Livestock Budgets }\end{array}$ \\
\hline Dyer, TN & $\begin{array}{l}\text { University of Tennessee Institute of Agriculture Field Crop Budgets for } 2015 \text { with } \\
\text { Conventional Tillage and Non-Irrigated }\end{array}$ \\
\hline Hancock, OH & $\begin{array}{l}\text { Ohio State University Department of Agricultural, Environmental, and } \\
\text { Development Economics } 2015 \text { Ohio Enterprise Budgets for Conservation Tillage }\end{array}$ \\
\hline Sheridan, KS & Kansas State University AgManger.info Farm Management Guides_Crops 2015 \\
\hline
\end{tabular}


260 Table 5 Commodity crop prices used for profitability analysis.

\begin{tabular}{ccc}
\hline Commodity & Price & Unit \\
\hline Corn & 5 & $\$ / \mathrm{bu}$ \\
Soybean & 11 & $\$ / \mathrm{bu}$ \\
Wheat & 5.5 & $\$ / \mathrm{bu}$ \\
Cotton & 0.8 & $\$ / \mathrm{lb}$ \\
Alfalfa & 175 & $\$ /$ ton \\
\hline Sorghum (milo) & 5 & $\$ / \mathrm{bu}$ \\
Non-Alfalfa Hay & 125 & $\$ /$ ton \\
\hline
\end{tabular}

261

Statistics of the 5-year average profitability are presented in Fig. 3 for all counties. The mean of the five-year average profitability of all counties are seen to be below zero; however, a significant fraction, though less than half, of subfields in all counties are seen to be profitable. Fig. 4 shows the spatial distribution of the five-year average profitability across the subfields in each county. Hancock and Sheridan Counties indicate significant number of subfields with profitability between $-\$ 100$ and zero.

Table 6 Land rental rates and sources for each county. In the case of Hancock and Fillmore counties, yield-specific

269 functions for calculating land rent based on productivity were used. The four remaining counties use an average land 270 rent for all fields.

\begin{tabular}{ccc}
\hline County & Land Rent & Source \\
\hline Castro, TX & $78 \$ /$ ac & NASS - 2010 to 2014 Average \\
Dyer, TN & $115 \$ / a c$ & NASS - 2010 to 2014 Average \\
\hline Hancock, OH & $\begin{array}{c}\text { Yield-based } \\
\text { function }\end{array}$ & Ohio State University 2014-2015 Land Rent Survey \\
Sheridan, KS & $74 \$$ ac & Kansas State University AgManager 2013/2014 Kansas County- \\
& Level Cash Rents for Non-Irrigated Cropland \\
\hline
\end{tabular}

\section{Sustainability}

273 As presented in Bonner et al. [47], four of the five biomass (residue) removal methods developed by Muth and

274 Bryden [8] were used for each combination of soil type and crop rotation. These are low residue harvest (0\%

275 removal), moderate residue harvest (35\% removal), moderately high residue harvest (52\% removal), and high

276 residue harvest (83\% removal). Bonner et al. [47] described two sets of sustainability criteria to protect the fields

277 from excessive soil and carbon removal. The first, basic, criterion, representing standard NRCS guidelines,

278 considered the biomass removal sustainable if (1) total soil erosion from wind and water was less than $T_{s}$, where $T_{s}$

279 (dry Mg/ha/y) is the reported tolerable annual factor, specific for each SSURGO soil map unit; and (2) if soil

280 organic matter depletion is low enough that a composite soil carbon index (SCI) was positive. The second, rigorous,

281 criterion required that the total erosion was less than $1 / 2 \mathrm{~T}_{\mathrm{s}}$ for each SSURGO unit and the SCI composite factor and 
SCI-OM organic sub-factor were both positive which ensured that the soil organic matter was either maintained or increased. The maximum sustainable residue removal for each subfield in a county in a year was estimated from

284 LEAF-generated total biomass for the year from the highest of the four removal methods that met the basic or 285 rigorous sustainability criterion.

\section{Energy Crop Harvesting}

Biomass removal rates for energy crop scenarios were calculated by the RUSLE2 model. RUSLE2 utilizes an internal crop growth model which estimates the amount of biomass growth in a season based on a user input target yield and weather data based on the location being modeled. A fraction of the simulated above ground biomass is then harvested based on a removal rate associated with the specified RUSLE2 harvest operation. Reported values represent the annual average biomass removal across the span of the simulated rotation. For example, for miscanthus, which has a planting to harvesting duration of 3 years, five life cycles are evaluated using the 20102014 conditions in each of the five cycles. The LEAF framework provides a standard set of management practices for energy crops which are directly applied to estimate yields. As these crops are more resilient than the row crops, can very efficiently remove nutrients and carbon from the soil [15], require less application of additional nutrients or carbon (making them more sustainable than row crops), are harvested with significant ground cover remaining, and their harvesting results in significantly less impacts on environment and agricultural sustainability than the harvesting of row crops, the LEAF framework estimates their contribution to total biomass without imposing any sustainability criterion.

\section{Feedstock Cost Estimation}

The logistics cost for biomass under the basic and rigorous sustainability control scenarios were based on a threepass corn (i.e., conventional) feedstock supply system as proposed in the 2017 Design case for Biological Conversion of Sugars to Hydrocarbons in Jacobson et al. [54]. In this design, the corn is harvested and windrowed using a flail shredder and then baled into large $(0.91$ X1.22X2.44-m) square bales. The harvest system for energy crops was based on the system described in the same reference ([54]) for switchgrass; in which the crop is cut and conditioned using a self-propelled mower and baled into large (0.91X1.22X2.44-m) square bales. The feedstock supply systems for each scenario included harvest and collection, transportation from field, as well as handling, storage and preprocessing at the conversion facility. The costs were based on delivering $881,849 \mathrm{dry} \mathrm{Mg} / \mathrm{y}$ to a conversion facility, without accounting for payment to the farmers or adjustments based on quality. The Biomass Logistics Model (BLM) was used to model feedstock logistics cost and energy consumption estimates for the proposed harvesting systems. The BLM incorporates information from a collection of databases that provide (1) engineering performance data for hundreds of equipment systems, (2) spatially explicit labor cost data sets, and (3) local tax and regulation data [55].

In order to account for the variability that occurs within a county, a Monte Carlo analysis was used to calculate a range of logistics costs (except for harvesting) for the counties. For each county, a thousand simulation runs were made in which the biomass yield was drawn from a triangular distribution based on the minimum, maximum, and 
317 mean of the yield data. This approach was also used to develop the relationships between the costs and energy crop 318 yield.

319 The impact of the use of precision agriculture in conjunction with precision conservation on harvest efficiency and costs was assessed for sub-field management scenarios where energy crops were integrated into the production of row crops. The results are intended to be compared to conventional, mono-crop field management to assess practicality of implementing sub-field management strategies. Geo-referenced crop production and field performance data were used in each county to simulate the harvest of the fields under conventional and sub-field management scenarios. The resulting harvesting cost information was combined with the crop establishment cost in both scenarios to form the basis of comparison.

326 The simulation of the harvests considered only infield movement and not the additional costs associated with staging 327 and setup of equipment. Field shape and characteristics were used to determine machine movement. For the conventional mono-crop case, simulation was carried out for only the fields that were capable of producing biomass under the identified sustainability criteria. Each subfield area that had a biomass removal limit greater than zero was selected and placed into the analysis data set. The sub-field areas that were placed into the analysis data set were then aggregated into field units based on adjacency and common land unit (CLU) identifier. The fields were then harvested based on user input values for machine width, percentage of overlap between machine passes, system cost per hour, harvest speed, and turning speed (Table 7). Harvesting begins with two machine passes around the perimeter of the field to create headlands, in which the machines can turn during harvest. After the two perimeter

335 passes, harvesting commences with the direction of travel parallel to the longest side of field. The distance traveled 336 during harvesting and turning is collected and divided by the harvest speed and turning speed, respectively, to determine the total harvest time for the field. Total harvest time, field area and field yield are then used to define the production per hour. The cost per hour was then divided by the production per hour to derive the cost per Mg for the 339 biomass feedstock.

340 Table 7. Equipment Assumptions Used for Harvest Simulations

\begin{tabular}{|l|c|c|c|c|}
\hline Table 7. Equipment Assumptions Used for Harvest Simulations \\
\hline & \multicolumn{2}{|c|}{ Crop residue } & \multicolumn{2}{|c|}{ Energy crop } \\
\hline & Harvester & Baler & Harvester & Baler \\
\hline Machine width (m) & 9.14 & 8.33 & 5.79 & 8.33 \\
\hline Machine speed (km/h) & 11.27 & 7.51 & 11.26 & 7.51 \\
\hline Macine efficiency (\%) & 95 & 95 & 95 & 95 \\
\hline Turn speed (km/h) & 5.63 & 5.63 & 5.63 & 4.00 \\
\hline Path overlap (\%) & 4 & 4 & 4 & 4 \\
\hline Harvesting cost (\$/h) & 108.00 & 138.29 & 119.12 & 169.85 \\
\hline
\end{tabular}

342 The sub-field management cases were handled slightly differently, with the analysis being handled in two parts. The crop residue from the primary crop is handled as above with the added assumption that sub-field areas that have an associated negative profit are removed from the analysis and the analysis continues as previously described. The

345 second part of the analysis dealt with the energy crop. For this analysis, the areas that are not profitable are the areas 346 that are selected for the analysis. The energy crop analysis followed the same steps for simulating the harvest after 
the selection of subfield areas. The final step in the subfield analysis was to combine the results of the two analyses to estimate the overall harvesting cost and total biomass.

349 The initial dataset for Sheridan County in Kansas contained information for 3,606 CLUs, and had 10,828 individual sub-field areas. Initial processing removed 1,279 of the sub-field areas that were unable to produce crop residue based on basic sustainability criteria. Sub-field areas that were less than 1 acre in size were also removed from further consideration from the perspective of operational practicality. The contiguous areas of the same CLU's were then joined to form operational areas, resulting in 3,327 operational areas that were carried forward for analysis. The harvesting parameters used for the analysis were based on the equipment utilized in the 2017 Feedstock Design Case [54], for the harvest of multi-pass corn stover. Equipment speeds were taken from the University of Georgia's Extension Engineering Handbook [56] and Iowa State University's Estimating the Field Capacity of Farm Machines

357 [57].

Simulation of the harvest was carried out as described above, starting with the mowing and windrowing of the stover and then followed by baling. Since, bailing followed immediately behind the mowing and windrowing, it was assumed that the baler followed the same path as the harvesting equipment. However, if there was the need for an additional raking step, the path followed by the raking equipment was calculated separately and the baler followed the raking path instead. Upon completion of the analysis, the results from the operational areas were aggregated to the CLU, to provide the results at the farm level. The relationship between the costs and yield are presented in Figs. 5 and 6 for crop residues and energy crops, respectively. Harvesting costs are separately presented in each figure from the other costs (preprocessing, transportation, and handling costs). Harvesting costs are clearly seen to be both a function of the yield and the specific subfield because the subfield geometries determine the direction of the harvesting pass and the time taken to harvest a field. The costs are generally seen to decrease with increasing yield for both residue and row crops. For a given yield, however, the cost can vary depending on the shape and size of the field. Harvesting costs for removing residues are seen to span a wider range than those for energy crops. The other costs are relatively stable with minor variations reflecting the inter-field differences in the transportation costs because of the differences in the number of trucks required to haul the biomass.

\section{Description of Analyses}

373 The following analyses were conducted using the LEAF framework and the methods described in the previous 374 sections.

375 1. A baseline assessment of row crop yields and profitability was conducted to determine grain productions and profitability for each of the 5 years (2010-2014) from every subfield analyzed in the four counties. For the baseline crop production, the 5 -year average biomass (residue) that could be harvested from each subfield under minimal and rigorous sustainability criteria was then estimated for the four counties and their respective states.

2. As the average 5-year profitability of each subfield for the grain production was known from the analyses in Step 1, non-profitable (5-year average profit $<=0$ ) subfields were identified and after accounting for the grain and biomass production lost from those subfields, the total county-specific grain and biomass production and profitability were estimated for the remaining subfields. 
3. Energy crop yields were simulated for the five-year period on the non-profitable row-crop subfields. Total biomass which includes grain-crops residues from profitable subfields and energy crop from non-profitable row-crop subfields were then estimated.

4. Finally, estimates of costs of harvesting, preprocessing, transportation, and handling were made for the biomass and energy crops assuming (1) all subfields are used for residual biomass and (2) a combination of profitable subfields for residual biomass and non-profitable subfields for energy crops are used. The assumptions and methods to assess feedstock costs were described in the previous section. The payments to farmers and adjustments based on quality are not included in the cost analyses as that data were not available for all states.

\section{Results}

\section{Grain and Biomass Availability}

The LEAF framework was used to assess the amounts of biomass available under the basic and rigorous sustainability criteria described earlier. Fig. 7 presents the 5 -year totals of grain and biomass availability in each county based on the grains grown and the rotation patterns in the subfields. Dyer and Sheridan Counties are representative of the minimum and maximum amounts of residual biomass harvests, respectively, under both basic and rigorous sustainability controls. Typically, less erodible soils would have less difference in the harvested amounts under basic and rigorous controls than highly erodible soils. The large variations in the differences of the amounts harvested under basic and rigorous controls from county to county suggests high variability in soil erosion and carbon retention capacities across counties. Both basic and rigorous sustainability controls placed very severe limitations on the amounts that could be harvested from Dyer County suggesting high potential for loss of nutrients and carbon from its soils should $100 \%$ removal of residue were to occur. Fig. 7 clearly shows that the amounts of biomass availability is significantly lower than the grain availability under both basic and rigorous sustainability controls.

\section{Profitability of Current Grain Production and Implications of Halting Production on Non- Profitable Subfields}

Fig. 8 shows the number of subfields in each county that are profitable and the number of profitable subfields with biomass production and Fig. 9 shows the number of subfields in each county that are non-profitable and the number of non-profitable subfields with biomass production. The number of non-profitable subfields are higher than the number of profitable subfields in all counties suggesting high potential for growing energy crops in all counties. Together, these figures suggest that sustainable production of residue-biomass cannot occur in all subfields, taking both profitable and non-profitable subfields into account; soil erodibility and carbon removal are important factors in determining the appropriate candidates for biomass removal, and higher protection against erosion and carbon loss would require less removal of biomass. As observed in both Figs. 4 and 9, Sheridan, KS, has the highest fraction of subfields that have 5-year average profits $\leq \$ 0$ followed by Hancock, $\mathrm{OH}$. These fractions have direct implications on the number of subfields that could be converted to energy crop production considering that production of residuebiomass on these subfields already makes a potentially significant contribution to the total production. 
Table 8 summarizes the impact of removing the non-profitable subfields from grain production altogether. As expected, Dyer, Hancock, and Sheridan counties lose the most acreage when grain crop production is halted in nonprofitable subfields. Both grain and biomass productions decrease significantly in these counties. However, for each county, the removal of these subfields results in positive and higher total 5-year profit simply by avoidance of nonprofitable grain production. The adjusted average profit also becomes positive or higher for all counties. However, the significant decrease in biomass would mean that reaching the BETO goal becomes more difficult under this option. A better solution is to use these subfields for bioenergy crop production if associated feedstock costs are acceptable to the bioenergy industry. Implications of using these subfields for energy crops are addressed in the next section.

Table 8 Impact of removing non-profitable subfields from grain production.

\begin{tabular}{|c|c|c|c|c|c|c|c|c|}
\hline \multirow[t]{2}{*}{$\begin{array}{l}\text { County } \\
\text { Name }\end{array}$} & \multirow[t]{2}{*}{$\begin{array}{l}\text { Net Grain } \\
\text { Production } \\
\text { (MMT) }\end{array}$} & \multicolumn{2}{|c|}{$\begin{array}{c}\text { Net Biomass } \\
\text { Production with } \\
\text { Control of Carbon } \\
\text { and Soil Losses } \\
\text { (MMT) }\end{array}$} & \multirow[t]{2}{*}{$\begin{array}{l}\text { \% Loss } \\
\text { in Acres }\end{array}$} & \multicolumn{2}{|c|}{$\begin{array}{l}\text { Profit from } \\
\text { Grains (\$M) }\end{array}$} & \multicolumn{2}{|c|}{$\begin{array}{c}\text { Average Profit from } \\
\text { Grains (\$/acre) }\end{array}$} \\
\hline & & $\begin{array}{c}\text { Basic } \\
\text { Control } \\
\end{array}$ & $\begin{array}{c}\text { Rigorous } \\
\text { Control }\end{array}$ & & Baseline & Adjusted & Baseline & Adjusted \\
\hline Castro, TX & 2.58 & 0.89 & 0.81 & 27 & $\$ 25.54$ & $\$ 44.21$ & $\$ 48.32$ & $\$ 83.64$ \\
\hline Dyer, TN & 0.97 & 0.02 & 0.00 & 50 & $-\$ 23.55$ & $\$ 66.37$ & $-\$ 25.54$ & $\$ 72.00$ \\
\hline Hancock, OH & 1.12 & 0.25 & 0.15 & 67 & $-\$ 18.20$ & $\$ 16.82$ & $-\$ 15.01$ & $\$ 13.87$ \\
\hline Sheridan, KS & 0.26 & 0.12 & 0.08 & 94 & $-\$ 115.93$ & $\$ 7.61$ & $-\$ 65.39$ & $\$ 4.29$ \\
\hline
\end{tabular}

\section{Implications of Replacing Non-Profitable Subfields with Energy Crops}

Estimates of energy crop production, according to Table 2, on non-profitable subfields are presented in Table 8, along with the baseline (current) grain and biomass production estimates, and in Fig. 10. Decrease in overall grain and biomass production for the 5-year period is partially compensated by energy crop production. As expected, the increase in total biomass (biomass from grain residues + energy crops) is minimal for Castro County because it has the least non-profitable fraction of land available for energy crop production (Figs. 4 and 9). In Castro County, most of the biomass contribution occurs from profitable subfields with very low production of energy crops on nonprofitable subfields indicating that the non-profitable subfields in the county are also non-productive. As the LEAF framework takes into account the type of energy crop grown, the climate, and soil properties to estimate the energy crop production, it is apparent that certain counties have the capacity to grow more energy crops than others. The energy crop production in Dyer, Hancock, and Sheridan Counties represent reasonably high multiples of the grain production and is considerably higher than the residue biomass production. While more energy crop is produced using basic erosion control measures, the \%-gain in total biomass production is typically higher under rigorous sustainability controls because we start off with lower biomass production under rigorous sustainability controls and baseline conditions. Energy crop production for both switchgrass and miscanthus, even on non-profitable grain fields, is significantly higher than the residue biomass production. Roughly $90 \%$ of subfields in Sheridan County and $72 \%$ of subfields in Hancock County are non-profitable with respect to grain production. Therefore, large 
potentials exist in these counties for the production of energy crops. An average subfield size in Hancock County is 5.6 acres whereas it is 33 acres in Sheridan

County, and there are 31,367 non-profitable subfields in Hancock County against 9,825 in Sheridan County. These factors and the individual, detailed farm-level assessment account for the significantly higher production and yields of miscanthus in Sheridan County over Hancock, and lower grain production in Sheridan County. Table 9 also provides the yields of residual biomass and energy crops in the four counties. For miscanthus, Mitchell et al. [15] report values between 2.5 to $17 \mathrm{metric}$ tons/ha/y in South and Southeastern regions where the yield potentials are low and $>30$ metric tons/ha/y in Illinois which has a high yield potential

452 for giant miscanthus. Considering that non-profitable sub-fields were evaluated for growing energy crops in this study, the yields in Table 9 for miscanthus are in 453 line with the reported values. The switchgrass yield for Dyer Count in Table 9 lies in the lower end of the yields of between 5.2 and 11 metric tons/ha/y reported in [15], consistent with the low productivity of the non-profitable subfields. Table 9 also shows the potential increase in total biomass produced by the integration of energy crops into the agricultural landscape over current baseline condition. Factors between 0.8 and 18.7 under the basic and between 0.8 and 21.2 under rigorous sustainability criteria, respectively, indicate significant potential for increased biomass production even on counties with less-productive soils.

Table 9 Impact of removing non-profitable subfields from grain production. All production numbers are for the 5-year period between 2010 and 2014 . In

459 Columns 3 and 4, biomass is available on all subfields under baseline conditions while, in Columns 6 and 7, biomass is available only from profitable subfields and the non-profitable subfields produce energy crops shown in Column 8.

\begin{tabular}{|c|c|c|c|c|c|c|c|c|c|c|c|c|}
\hline \multirow[t]{2}{*}{$\begin{array}{l}\text { County } \\
\text { Name }\end{array}$} & \multicolumn{4}{|c|}{$\begin{array}{l}\text { Biomass with Control } \\
\text { of Carbon and Soil } \\
\text { Losses (MMT) }\end{array}$} & \multicolumn{2}{|c|}{$\begin{array}{l}\text { Biomass with } \\
\text { Control of } \\
\text { Carbon and Soil } \\
\text { Losses (MMT) }\end{array}$} & \multirow[t]{2}{*}{$\begin{array}{c}\text { Energy } \\
\text { Crop } \\
\text { Production } \\
\text { (MMT) }\end{array}$} & \multicolumn{2}{|c|}{$\begin{array}{l}\text { Fold-increase in total } \\
\text { biomass from energy } \\
\text { crop integration }\end{array}$} & \multicolumn{3}{|c|}{ Average Yield (MT/ha/y) } \\
\hline & $\begin{array}{l}\text { Grains } \\
\text { (MMT) }\end{array}$ & $\begin{array}{c}\text { Basic } \\
\text { Control }\end{array}$ & $\begin{array}{c}\text { Rigorous } \\
\text { Control }\end{array}$ & $\begin{array}{l}\text { Grains } \\
\text { (MMT) }\end{array}$ & $\begin{array}{c}\text { Basic } \\
\text { Control }\end{array}$ & $\begin{array}{l}\text { Rigorous } \\
\text { Control }\end{array}$ & & $\begin{array}{c}\text { Basic } \\
\text { Control }\end{array}$ & $\begin{array}{l}\text { Rigorous } \\
\text { Control }\end{array}$ & $\begin{array}{l}\text { Biomass, } \\
\text { Basic } \\
\text { Control }\end{array}$ & $\begin{array}{c}\text { Biomass, } \\
\text { Rigorous } \\
\text { Control } \\
\end{array}$ & $\begin{array}{l}\text { Energy } \\
\text { Crops }\end{array}$ \\
\hline $\begin{array}{l}\text { Castro, TX } \\
\text { (Sorghum) }\end{array}$ & 3.86 & 1.14 & 1.03 & 2.58 & 0.89 & 0.81 & 0 & 0.8 & 0.8 & 7.57 & 7.21 & 0.00 \\
\hline $\begin{array}{l}\text { Dyer, TN } \\
\text { (Switchgrass) }\end{array}$ & 1.45 & 0.03 & 0.00 & 0.97 & 0.02 & 0.00 & 0.54 & 18.7 & N/A & 1.65 & 0.00 & 5.63 \\
\hline $\begin{array}{l}\text { Hancock, OH } \\
\text { (Miscanthus) }\end{array}$ & 2.87 & 0.90 & 0.43 & 1.12 & 0.25 & 0.15 & 2.15 & 2.7 & 5.3 & 3.53 & 4.60 & 9.51 \\
\hline $\begin{array}{l}\text { Sheridan, KS } \\
\text { (Miscanthus) }\end{array}$ & 2.56 & 1.45 & 0.28 & 0.26 & 0.12 & 0.08 & 5.85 & 4.1 & 21.2 & 3.48 & 3.63 & 9.72 \\
\hline
\end{tabular}




\section{Estimates of Feedstock Logistics Cost}

Unlike grain production, it is currently not possible to evaluate profits from biomass and energy crop production in a realistic manner as the markets for feedstock have not been established because trade volumes are low. However, because of advances made in the estimation of the costs of biomass harvesting and collection, handling, transportation, and preprocessing, it is possible to estimate them and get an appreciation of the state of science viz the BETO goal of $\$ 84 /$ dry short ton in $2014 \$$ by 2017 [2]. As discussed in the Materials and Methods Section, the harvesting costs were estimated at the farmer (CLU) level rather than at subfield-level, and subfields less than 1 acre in size within a CLU were not included for the estimation of either energy crop amounts or its logistics cost. Costs of biomass production from all of the currently operational subfields are presented in Table 10 under the basic and rigorous sustainability controls. It should be noted that the harvesting costs do not reflect the costs of staging equipment for harvesting operations because the subfields are scattered across the landscapes. The scattered distribution of subfields makes time for equipment moving and set-up a significant part of the harvesting costs and the reported costs in Table 10 would therefore represent an underestimation.

Using the general trends observed in Figs. 5 and 6 that the average harvesting costs, and therefore, the total costs are inversely proportional to the biomass yield, Table 10 indicates that because Castro, Hancock, and Sheridan Counties contain the higher-yield subfields, they are likely to have lower overall average logistics cost for the biomass production under both basic and rigorous sustainability controls. It should be noted that the average residue biomass yield in Castro County is considerably higher than from the other counties (Table 9) although the range of yields in the county varies from 0.92 to 10.2 dry metric tons/ha. Compared to other counties, Dyer contains both low-yielding and lower acreage subfields, making its costs higher. For Sheridan County, the average payment to farmer results in an add-on of upwards of $\$ 30.95 /$ dry metric ton to the total cost and result in feedstock costs of upwards of $\$ 83.28$ and $\$ 81.98$ per dry metric ton under basic and rigorous controls, respectively. The compensating effects of lower yields and higher costs on total cost, is apparent in Table 10; i.e., the lower yields from rigorous sustainability controls comes at a higher cost resulting in a compensatory effect on the costs for the two criteria. 
Table 10 Estimated average costs of feedstock supply-chain components for biomass production in existing subfields (in 2014\$).

\begin{tabular}{|c|c|c|c|c|c|c|c|c|c|c|}
\hline \multirow{2}{*}{ County } & \multicolumn{5}{|c|}{ Biomass Production Costs with Basic Controls (\$/MT) } & \multicolumn{5}{|c|}{ Biomass Production Costs with Rigorous Controls (\$/MT) } \\
\hline & Harvesting & Preprocessing & Transportation & Handling & Total & Harvesting & Preprocessing & Transportation & Handling & Total \\
\hline Castro, TX & $\$ 6.35$ & $\$ 22.24$ & $\$ 8.12$ & $\$ 1.82$ & $\$ 38.52$ & $\$ 6.64$ & $\$ 22.21$ & $\$ 8.17$ & $\$ 1.81$ & $\$ 38.84$ \\
\hline Dyer, TN & $\$ 37.72$ & $\$ 22.23$ & $\$ 11.31$ & $\$ 1.81$ & $\$ 73.08$ & $\$ 0.00$ & $\$ 0.00$ & $\$ 0.00$ & $\$ 0.00$ & $\$ 0.00$ \\
\hline Hancock, $\mathrm{OH}$ & $\$ 17.41$ & $\$ 22.25$ & $\$ 9.47$ & $\$ 1.82$ & $\$ 50.95$ & $\$ 14.02$ & $\$ 22.25$ & $\$ 9.03$ & $\$ 1.82$ & $\$ 47.12$ \\
\hline Sheridan, KS & $\$ 18.13$ & $\$ 22.25$ & $\$ 10.13$ & $\$ 1.82$ & $\$ 52.33$ & $\$ 17.05$ & $\$ 22.25$ & $\$ 9.92$ & $\$ 1.82$ & $\$ 51.03$ \\
\hline
\end{tabular}

MT represents dry metric ton. 
Table 11 provides the estimated logistics costs for the scenario depicted in Table 9 where energy crop is produced in non-profitable grain-subfields and residual biomass is produced in profitable grain-subfields. Significant changes in costs occur as a result of harvesting energy crops in all counties except Castro, where the changes from Table 10 merely reflect the zero residue-harvesting from non-profitable subfields (i.e., does not reflect energy crop production). The reduction in average total cost is particularly significant for Dyer County where the energy crops constitutes the majority of biomass produced. The harvesting and total costs in all three counties with energy crop production go down as a result of significant energy crop production at higher yields. For Sheridan County in Kansas, the total feedstock cost with the grower payment included reduced further from the baseline scenario to upwards of $\$ 76.87$ and $\$ 76.85$ per dry metric ton of biomass, considerably lower than the BETO goal of $\$ 84 /$ dry short ton (= \$92.6/dry metric ton) in 2017 at 2014\$ [2]. It should also be noted from Table 11 that energy crop yields are the lowest in Dyer County, leading to the higher logistics costs there than the other counties. The reasons for the lower costs in Sheridan County over Hancock County have already been partially explained in the discussion on Table 9. It should also be noted that because of the significantly larger quantities of energy crops being produced in Hancock and Sheridan Counties, their transportation costs actually go up over the baseline values even though other costs go down resulting in higher average total cost for Hancock County over the baseline value. An illustrative comparison of the estimated average total feedstock logistics cost in $2014 \$$ is provided in Fig. 11, which combine the results from Tables 10 and 11. 
Table 11 Estimated average costs of feedstock supply-chain components for energy crop production from non-profitable grain-subfields and biomass production from profitable grain-subfields (in 2014\$).

\begin{tabular}{|c|c|c|c|c|c|c|c|c|c|c|c|c|c|}
\hline \multirow{2}{*}{$\begin{array}{l}\text { County, } \\
\text { Energy Crop }\end{array}$} & \multicolumn{5}{|c|}{$\begin{array}{c}\text { Total Biomass (including Energy Crops) Production } \\
\text { Costs with Basic Controls (\$/MT) }\end{array}$} & \multicolumn{5}{|c|}{$\begin{array}{c}\text { Total Biomass (including energy crops) Production Costs } \\
\text { with Rigorous Controls (\$/MT) }\end{array}$} & \multicolumn{3}{|c|}{ Average Yield (MT/ha) } \\
\hline & Harvesting & $\begin{array}{c}\text { Pre- } \\
\text { processing }\end{array}$ & $\begin{array}{l}\text { Transpo- } \\
\text { rtation }\end{array}$ & Handling & Total & Harvesting & $\begin{array}{c}\text { Pre- } \\
\text { processing }\end{array}$ & $\begin{array}{c}\text { Transpo- } \\
\text { rtation }\end{array}$ & Handling & Total & $\begin{array}{c}\text { Biomass, } \\
\text { Basic } \\
\text { Control }\end{array}$ & $\begin{array}{c}\text { Biomass, } \\
\text { Rigorous } \\
\text { Control }\end{array}$ & $\begin{array}{c}\text { Energy } \\
\text { Crops }\end{array}$ \\
\hline $\begin{array}{l}\text { Castro, TX, } \\
\text { Sorghum }\end{array}$ & $\$ 6.85$ & $\$ 22.24$ & $\$ 8.05$ & $\$ 1.82$ & $\$ 38.96$ & $\$ 7.14$ & $\$ 22.22$ & $\$ 8.10$ & $\$ 1.81$ & $\$ 39.27$ & 7.57 & 7.21 & 0.00 \\
\hline $\begin{array}{l}\text { Dyer, TN, } \\
\text { Switchgrass }\end{array}$ & $\$ 23.49$ & $\$ 19.99$ & $\$ 15.62$ & $\$ 1.81$ & $\$ 60.91$ & $\$ 22.82$ & $\$ 19.91$ & $\$ 15.78$ & $\$ 1.81$ & $\$ 60.32$ & 1.65 & 0.00 & 5.63 \\
\hline $\begin{array}{l}\text { Hancock, } \mathrm{OH}, \\
\text { Miscanthus }\end{array}$ & $\$ 14.31$ & $\$ 20.18$ & $\$ 14.58$ & $\$ 1.82$ & $\$ 50.89$ & $\$ 13.44$ & $\$ 20.09$ & $\$ 14.79$ & $\$ 1.82$ & $\$ 50.13$ & 3.53 & 4.60 & 9.51 \\
\hline $\begin{array}{l}\text { Sheridan, KS, } \\
\text { Miscanthus }\end{array}$ & $\$ 9.05$ & $\$ 19.99$ & $\$ 15.07$ & $\$ 1.82$ & $\$ 45.92$ & $\$ 9.00$ & $\$ 19.97$ & $\$ 15.11$ & $\$ 1.82$ & $\$ 45.90$ & 3.48 & 3.63 & 9.72 \\
\hline
\end{tabular}




\section{Reduction in Food Production and Revisiting the Bioenergy Production}

Table 9 also presents the reduction in grain production from production of energy crops on non-profitable subfields. These reductions are summarized in Fig. 12 and show that Sheridan, KS, and Hancock, OH, will have significant reductions in grain production that could potentially affect the grain industry. In these counties, because of the availability of large fractions of non-profitable subfields, the production of bioenergy crops on all of them would result in considerable reduction in total grain production in those area. While it is true that replacing the subfields with bioenergy crops would cause an overall reduction in national grain production, the results from the two mentioned counties would not be representative of the effect on the entire grain production system, since it is likely that an area with high proportions of unprofitable fields would contribute highly to the total quantity of grain produced. However, the impact of replacing grain crops with dedicated bioenergy crops on national grain availability is an important issue and will be investigated further as our research continues.

The food production issue also compels one to revisit the high variability observed in Figs. 5 and 6 in the harvesting costs; each point in these figures being representative of a farm (CLU), some of the harvesting costs can be seen to be prohibitively high. The harvesting costs are plotted as histograms in Fig. 13 and it can be seen that there is a significantly high number of CLUs in which the harvesting costs are higher than the average costs reported in Tables 10 and 11 and Fig. 11.

Fig. 13 also shows that there are CLUs that contain profitable (for grain production) subfields in which harvesting of residue-biomass is cost-prohibitive. Ability to conduct CLU-level cost analysis permits the culling of low-cost CLUs from the list of profitable and non-profitable sub-fields for the harvest of residue and energy crops, respectively. This process is summarized for Dyer County in Fig. 14. Selecting maximum allowable harvesting cost and minimum permissible yields (the values shown in Fig. 14 are for illustration purposes only), it is possible to carve out the green quadrants containing CLUs on which residue and energy crops can be produced at acceptable harvesting costs. While it would lower the amount of total biomass produced, it could also reduce the impact on food production, if the results of the two counties are assumed to be representative of the national-scale behavior, considerably. As the study is extended to more counties and states, the impact on food production as well as the importance of variability in biomass harvesting costs will be included as essential components of the integrated landscape management.

\section{Conclusions}

The analyses presented in this document shows that biomass can be produced either (1) by harvesting biomass from existing subfields where grains are grown or (2) by harvesting biomass on profitable subfields while growing and harvesting energy crops on non-profitable subfields. Both alternatives result in significant increases in biomass with the latter alternative producing more total biomass than the former. As the biomass prices are still controlled by a sparsely distributed, experimental, and unestablished market conditions, it is difficult to estimate the profitability of either alternatives. However, the analysis of logistics costs, particularly the analysis of precision harvesting to collect residues and energy crops, clearly indicates that addition of energy crops actually results in a significant decrease in average total costs while also increasing the production of total biomass. The analysis presented here 
also points out the influence of yields, acreage and the yield-cost relationship in determining the final unit cost of feedstock production. Another important finding that emerges from this analysis is that for increased-quantity and lower-cost production of biomass, it is important to grow energy crops as well.

Among the four counties studied, Sheridan and Kansas Counties, with the higher fractions of non-profitable fields, present the highest potential for integration of energy crops in row-crop fields and biomass production. Therefore, these and other counties with large fractions of non-profitable row crop fields, are most likely to benefit from the changes in management practices and land use presented in this study. Subfield-row-crop profitability constitutes the single-most important factor in the determination of energy crop integration; therefore, it is important to verify and validate row-crop profitability using real data from growers and to understand the key parameters that contribute most to its variability so that energy crop integration is based on estimates of profitability that are both reliable and less uncertain.

When focus is turned to the variability in harvesting cost at the CLU-level, a major contributor to the total logistics cost, it is immediately apparent that it is not profitable (and therefore, not sustainable) to harvest residual biomass from certain profitable subfields and energy crops from certain non-profitable subfields. Harvesting costs could be further improved and made more realistic by including equipment moving and staging costs and therefore, the reported harvesting costs, while being state-of-the-art, may not be truly representative. Because of the scattered locations of the subfields, it is a major challenge to optimize this process. This study provides a method to isolate subfields and CLUs on which residual biomass and energy crops can be produced in a sustainable manner at lower cost. While the analysis on the total biomass production from the application of this method was not conducted as part of the current research as it was out of the current scope, it does provide the promise for increased biomass production with limited impact on food production. The grain-profitability-based identification of CLUs for residue and energy crop production and the variability-based culling of sustainable CLUs provide a systematic approach to investigate the quantity and cost of biomass production in the US.

\section{Acknowledgments}

This work was supported by the US Department of Energy's Office of Energy Efficiency and Renewable Energy, Bioenergy Technologies Office, under DOE Idaho Operations Office Contract DE-AC07-05ID14517. Accordingly, the US Government retains a nonexclusive, royalty-free license to publish or reproduce the published form of this contribution, or allow others to do so, for US Government purposes. The authors would also like to acknowledge the analytical support provided by AgSolver to this study.

\section{References}

[1] Sissine, F. (2007). Energy Independence and Security Act of 2007: a summary of major provisions, DTIC Document.

[2] Schwab, A. (2016) Bioenergy Technologies Office Multi-Year Program Plan: March 2016, Bioenergy Technologies Office. 
[3] Heaton, E. A., Dohleman, F. G., Long, S. P. (2008) Meeting US biofuel goals with less land: the potential of Miscanthus. Global Change biology 14(9): 2000-2014.

[4] Dale V. H., Kline K. L., Wright L. L., Perlack R. D., Downing M., Graham R. L. (2011) Interactions among bioenergy feedstock choices, landscape dynamics, and land use. Ecol. Appl. 21(4):1039-54.

[5] Muth, D. J., McCorkle, D. S., Koch, J. B., Bryden, K. M. (2012) Modeling Sustainable Agricultural Residue Removal at the Subfield Scale. Agronomy Journal 104(4): 970.

[6] Muth, D. J., Bryden, K. M., Nelson, R. G. (2013) Sustainable agricultural residue removal for bioenergy: A spatially comprehensive US national assessment. Applied Energy 102:403-417.

[7] Bonner I. J., Cafferty K. G., Muth D. J.,Koch, J. B., Karelen, D. L. (2014a) Modeled impacts of cover crops and vegetative barriers on corn stover availability and soil quality. Bioenerg. Res. 7(10):6509-6526. PubMed PMID: doi:10.3390/en7106509.

[8] Muth D. J., Bryden K. M. (2013) An integrated model for assessment of sustainable agricultural residue removal limits for bioenergy systems. Environmental Modelling \& Software 39:50-69.

[9] Vogel K. P. (2004) Switchgrass. In: Moser LE, Burson BL, Sollenberger LE (eds) Warm-season (C4) Grasses. ASA-CSSA-SSSA, Madison, pp 561-588.

[10] Fedenko, J. R., Erickson, J. E., Woodard, K. R., Sollenberger, L. E., Venramini, J. M. B., Gilbert, R. A., Helsel, Z. R., Peter G. F. (2013) Biomass production and composition of perennial grasses grown for bioenergy in a subtropical climate across Florida, USA. Bioenerg. Res. 6:1082-1093.

[11] Kiniry, J. R., Anderson, L. C., Johnson, M. V., Behrman, K. D., Brakie, M., Burner, D. M., Cordsiemon, R. L., Fay, P. A., Fritschi, F. B., Houx, J. H. III, Hawkes, C., Juenger, T., Kaiser, J., Keitt, T., Lloyd-Reilley, J., Maher, S., Raper, R., Scott A., Shadow, A., West, C., Wu, Y., Zibilske, L.M. (2013) Perennial biomass grasses and the Mason-Dixon line: comparative productivity across latitudes in the southern Great Plains. BioEnergy Res 6:276-291.

[12] Shoemaker, C. E., Bransby, D. I. (2011) The role of sorghum as a bioenergy feedstock In: R. Braun, D.L. Karlen, and D. Johnson (eds.) Sustainable Alternative Fuel Feedstock Opportunities, Challenges and Roadmaps for Six U.S. Regions. Proceedings of the Sustainable Feedstocks for Advanced Biofuel Workshop. Sept. 27-29, 2010. Atlanta, GA. Soil and Water Conservation Society, Ankeny, IA 50023 149-159.

[13] Knoll, J. E., Johnson, J. M., Huang, P., Lee R. D., Anderson, W. F. (2015) Effects of delayed winter harvest on biomass yield and quality of napiergrass and energycane. Biomass Bioenergy 80:330-337. doi: 10.1016/j.biombioe.2015.06.018.

[14] Knoll, J. E., Anderson, W. F., Strickland, T. C., Hubbard, R. K., Malik, R. (2012) Low-input production of biomass from perennial grasses in the Coastal Plain of Georgia, USA. Bioenerg. Res 5:206-214. 
[15] Mitchell, R. B., Schmer, M. R., Anderson, W. F., Jin, V., Blakcom, K. S., Kiniry, J. (2016) Dedicated Energy Crops and Crop Residues for Bioenergy Feedstocks in the Central and Eastern USA. Bioenerg. Res. 9:384398. DOI 10.1007/s12155-016-9734-2.

[16] Gelfand, I., Zenone, T., Jasrotia, P., Chen, J., and Hamilton, S. K. (2011) Carbon debt of Conservation Reserve Program (CRP) grasslands converted to bioenergy production. Proc. Natl. Acad. Sci. USA 108:13864-13869.

[17] Jungers, J. M., Fargione, J. E., Sheaffer, C. C., Wyse, D. L., Lehman, C. (2013) Energy potential of biomass from conservation grasslands in Minnesota, USA. PLoS One 8(4):e61209.

[18] Tillman, D., Hill, J., Kehman, C. (2006) Carbon-negative biofuels from low-input high-diversity grasslands biomass. Science 314:1598-1600.

[19] Corton, J., Bühle, L., Wachendorf, M., Donnison, I. S., Fraser, M. D. (2013) Bioenergy as a biodiversity management tool and the potential of a mixed species feedstock for bioenergy production in Wales. Bioresour. Technol. 129:142-149.

[20] Zhou, X. P., Xiao, B., Ochieng, R. M., Yang, J. K. (2009) Utilization of carbon-negative biofuels from lowinput high-diversity grassland biomass for energy in China. Renew. Sustain. Energy Rev. 13:479-485.

[21] Barbosa, B., Boleo, B., Sidella, S., Costa, J., Duarte, M. P., Mendes, B., Cosentino, S. L., Fernando, A. L. (2015) Phytoremediation of heavy metal-contaminated soils using the perennial energy crops Miscanthus spp. and Arundo donax L. Bioenerg. Res. 8:1500-1511. DOI 10:1007/s12155-015-9688-9.

[22] Werling, B. P., Dickson, T. L., Isaacs, R., Gaines, H., Gratton, C., Gross, K. L., Liere, H., Malmstrom, C. M., Meehand, T. D., Ruan, L., Robertson, B. A., Robertson, G. P., Schmidt, T. M., Schrotenboer, A. C., Teal, T. K., Wilson, J. K., Landis, D. A. (2014) Perennial grasslands enhance biodiversity and multiple ecosystem services in bioenergy landscapes. Proceedings of National Academy of Sciences (PNAS), Vol. 111, No. 4, 1652-1657.

[23] Hughes, J. K., Lloyd, A. J., Huntingford, C., Finch, J. W., Harding, R. J. (2010) The impact of extensive planting of Miscanthus as an energy crop on future CO2 atmospheric concentrations. GCB Bioenergy 2:79-88.

[24] Hedde, M., F. van Oort, E. Boudon, F. Abonnel, and I. Lamy. (2013) Responses of soil macroinvertebrate communities to Miscanthus cropping in different trace metal contaminated soils. Biomass Bioenergy 55:122129.

[25] Bourke, D., Stanley, D. A., O’Rourke, E., Thompson, R., Carnus, T., Dauber, J. Emmerson, M, Whelan, P., Hecq, F., Flynn, E., Dolan, L., Stout, J. (2014) Response of farmland biodiversity to the introduction of bioenergy crops: effects of local-factors and surrounding landscape context. GCB Bioenergy 6:275-289.

[26] Donnison, I. S., Fraser, M. D. (2016) Diversification and use of bioenergy to maintain future grasslands. Food and Energy Security. 5(2):67-75.

[27] Fernando, A. L., Boleo, S., Barbosa, B., Costa, J., Duarte, M. P., Monti, A. (2015) Perennial grass production opportunities in marginal Mediterranean land. Bioenerg. Res. 8:1523-1537. DOI 10.1007/s12155-015-9692-0. 
[28] Dale, V. H., Kling, C., Meyer, J. L., Sanders, J., Stallworth, H., Armitage, T., Wangsness, D., Bianchi, T., Blumberg, A., Boynton, W., Conley, D. J., Crumpton, W., David, M. B., Gilbert, D., Howarth, R. W., Lowrance, R., Mankin, K., Opaluch, J., Pearl, H., Reckhow, K., Sharpley, A. N., Simpson, T. W., Snyder, C., Wright, D. (2010) Hypoxia in the Northern Gulf of Mexico. Springer Series on Environmental Management. ISBN 0172-6161, ISBN 978-0-387-89685-4, e-ISBN 978-0-387-89686-1, DOI 10.1007/978-0-387-89686-1. Springer New York.

[29] Smith, V. H., Tilman, G. D., Nekola, J. C. (1999) Eutrophication: Impacts of excess nutrient inputs on freshwater, marine, and terrestrial ecosystems. Environmental Pollution 100(1-3):179-196.

[30] Min, Q. W., Jiao. Y. L. (2002) Effects of agricultural non-point source pollution on Eutrophication of water body and its control measure. Acta Ecological Sinica. 2002-03.

[31] Jager, H. I., Baskaran, L. M., Schweizer, P.E., Turhollow, A. F., Brandt, C. C., Srinivasan, R. (2015) Forecasting changes in water quality in rivers associated with growing biofuels in the Arkansas-White-Red river drainage, USA. GCB Bioenergy 7:774-784. DOI: 10.1111/gcbb.12169.

[32] Dodds, W. K., Oakes R. M. (2008) Headwater influences on downstream water quality. Environmental Management, 41:367-377.

[33] Negri, M. C. (2016) Bioenergy Sustaianbility and the Food, Energy, Land and Water Nexus. Presented at DOE’s Bioenergy Solutions to Gulf Hypoxia Workshop. Aug 30-31, 2016, Washington, DC.

[34] Wu, M. (2016) Modeling water quality in the Mississippi River Basin: Upper Mississippi, Ohio, and Missouri River Basins. Presented at DOE’s Bioenergy Solutions to Gulf Hypoxia Workshop. Aug 30-31, 2016, Washington, DC.

[35] McIsaac, G. F. (2016) Framing the problem: Nutrient source identification, accounting, and attribution. Presented at DOE's Bioenergy Solutions to Gulf Hypoxia Workshop. Aug 30-31, 2016, Washington, DC.

[36] Demissie, Y., Yan, E., Wu. M., Zhang, Z. (2012) Watershed modeling of potential impacts of biofuel feedstock production in the Upper Mississippi River Basin. Environmental Sciences Division, Argonne National Laboratory Report, ANL/EVS/AGEM/TR-12-07, April 2012.

[37] Nocentini, A., Virgilio, N. D., Monti, A. (2015) Model Simulation of Cumulative Carbon Sequestration by Switchgrass (Panicum Virgatum L.) in the Mediterranean Area using the DAYSENT Model. Bioenerg. Res. 8:1512-1522. DOI 10.1007/s12155-015-9672-4.

[38] Cosentino, S. L., Copani, V., Scalici, G., Scordia, D., Testa, G. (2015) Soil erosion mitigation by perennial species under Mediterranean environment. Bioenerg. Res. 8:1538-1547.

[39] Blanco-Conqui, H., Gantzer, C. J., Anderson, S. H., Alberts, E. E., Thompson, A. L. (2004) Grass barrier and vegetative filter strip effectiveness in reducing runoff, sediment, nitrogen, and phosphorus loss. Soil Sci. Soc. Am. J. 68:1670-1678. 
[40] Selman, M. (2016) Office of environmental markets: Water quality trading and synergies with BETO. Presented at DOE's Bioenergy Solutions to Gulf Hypoxia Workshop. Aug 30-31, 2016, Washington, DC.

[41] Reed, D. (2016) Supply and demand for ecosystem credits. Presented at DOE's Bioenergy Solutions to Gulf Hypoxia Workshop. Aug 30-31, 2016, Washington, DC.

[42] Fox, J. (2016) Monetizing ecosystem services and other challenges. Presented at DOE's Bioenergy Solutions to Gulf Hypoxia Workshop. Aug 30-31, 2016, Washington, DC.

[43] Biomass Crop Assistance Program (BCAP). https://www.fsa.usda.gov/programs-and-services/energyprograms/BCAP/index (accessed on December 01, 2016).

[44] Millennium Ecosystem Assessment. (2005) Living beyond Our Means: Natural Assets and Human WellBeing. Island Press, Washington.

[45] Mueller, N. D., Gerber, J. S., Johnston, M., Deepak, K. R., Ramankutty, M., Foley, J. A. (2012) Closing yield gaps through nutrient and water management. Nature (Published online 29 August 2012) doi: 10.1038/nature 11420.

[46] Follett, F. F., Vogel, K. P., Varvel, G. E., Mitchell, R. B., Kimble, J. (2012) Soil carbon sequestration by switchgrass and no-till maize grown for bioenergy. Bioenerg. Res. 5:866-875.

[47] Bonner I. J., Muth D. J., Tomer M. D., James D. E., Porter S. A., Karelen, D. L. (2014b) Opportunities for Energy Crop Production Based on Subfield Scale Distribution of Profitability. Energies 7(10):6509-26. PubMed PMID: doi:10.3390/en7106509.

[48] Bonner, I. J., Mcunn, G., Muth, D. J., Tyner, W., Leirer, J., Dakins, M. (2016) Development of integrated bioenergy production systems using precision conservation and multimedia decision analysis techniques. J. Soil and Water Conserv. 71(3): 180-191.

[49] Rooney, W. L. (2000) Sorghum. Cellulosic Energy Cropping Systems, 109-129.

[50] McKendry, P. (2002) Energy production from biomass (part 1): overview of biomass. Bioresource technology 83(1), 37-46.

[51] Revised Universal Soil Loss Equation, Version 2 (RUSLE2), Official NRCS RUSLE2 Program. Official NRCS Database. http://fargo.nserl.purdue.edu/rusle2_dataweb/RUSLE2_Index.htm.

[52] Scheffe, L., Ferruzzi, G., Boetger, S., and Woodruff, S. (2015) RUSLE2 Advanced Data Management. http://fargo.nserl.purdue.edu/RUSLE2_ftp/NRCS_Base_Database/RUSLE2\%20Instructional\%20Mat erial/Training\%20Presentations/RUSLE2\%20Advanced\%20Data\%20Management.pptx.

[53] Cotton News. (2011) County production figures. https://www.plainscotton.org/esw/news/cotnewsback/2012/ CN120511.htm.

[54] Jacobson, J. J., Roni, M. S., Lamers, P., Cafferty, K. G. (2014) Biomass Feedstock and Conversion Supply System Design and Analysis. Idaho National Laboratory, Idaho Falls, ID. INL/EXT-14-32377.

[55] Cafferty, K. G., Muth, D. J., Jacobson, J. J., Bryden, K. M, (2013a) Model Based Biomass System Design of Feedstock Supply Systems for Bioenergy Production. In: ASME 2013 International Design Engineering 
Technical Conferences and Computers and Information in Engineering Conference, August 4-7, Portland, OR, USA.

[56] University of Georgia's Extension Engineering Handbook. http://www.caes.uga.edu/departments/bae/extension/handbook/\#geninfo.

[57] Hanna, M. (2016) Estimating the Field Capacity of Farm Machines. Iowa State University, Extension and Outreach, Ames, IA. PM 696. Available from https://www.extension.iastate.edu/agdm/crops/pdf/a3-24.pdf. 


\section{FIGURES}
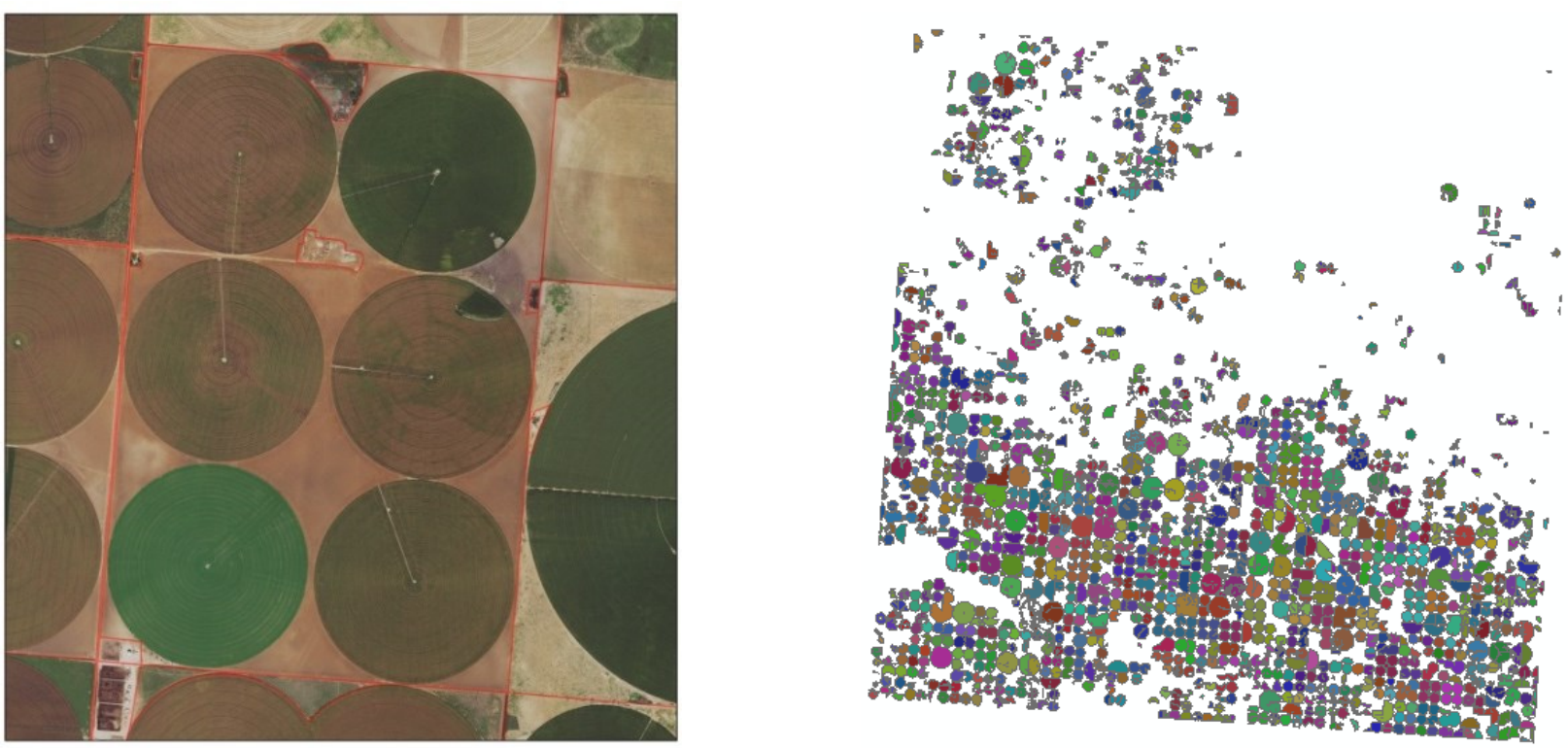

\section{CLU Boundary}

Fig 1 Comparison of the Common Land Unit (CLU) boundaries to actual management areas in Castro County, TX (left). Field boundaries created by converting the Cropland Data Layer land cover into polygons based on similar 5year rotations (right). 


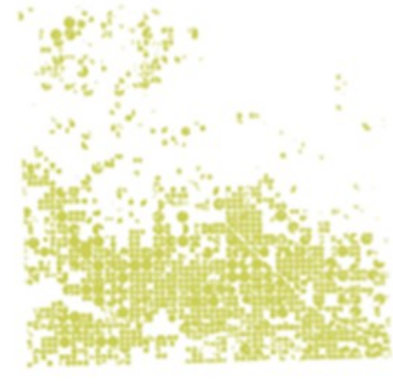

Castro County, TX

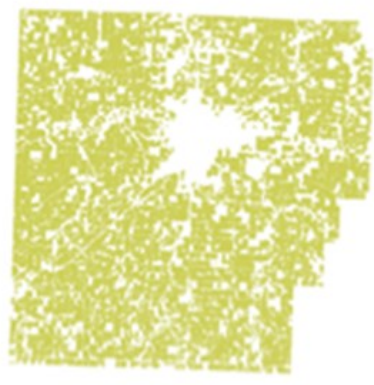

Hancock County, $\mathrm{OH}$

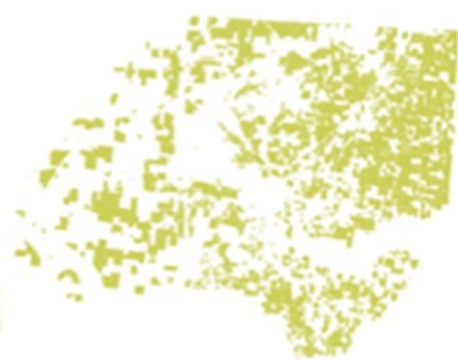

Dyer County, TN

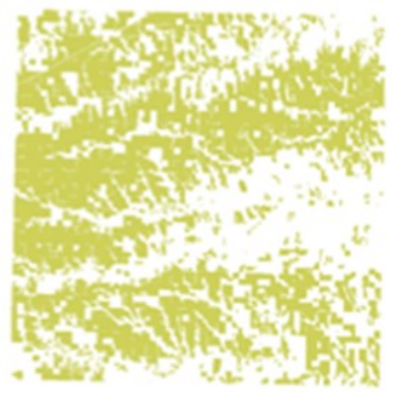

Sheridan County, KS

Fig 2 Fields meeting analysis criteria in each of the four counties. 


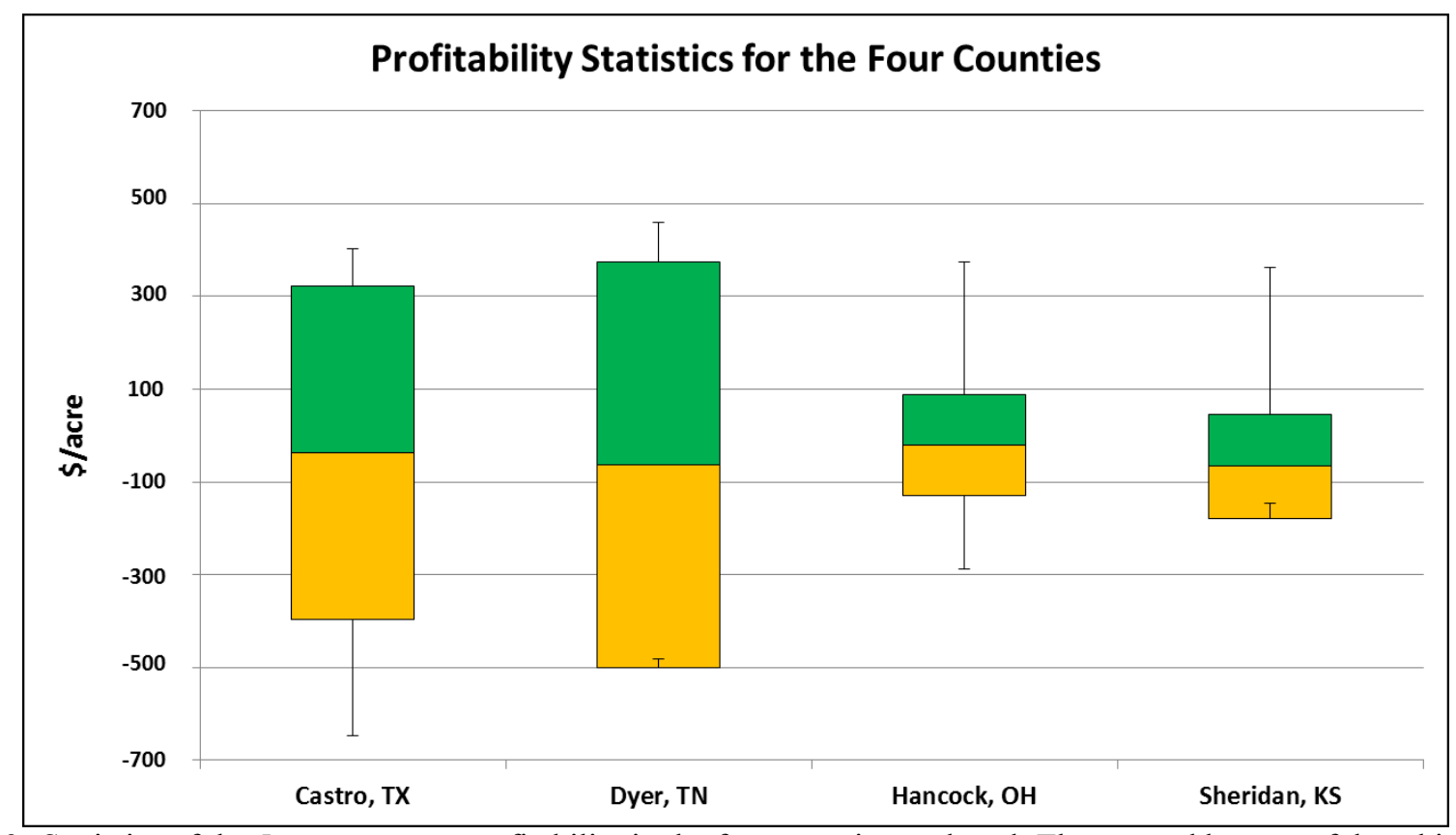

Fig 3 Statistics of the 5-year average profitability in the four counties analyzed. The top and bottom of the whiskers for each county represent the estimated maximum and minimum grain profitability. The intersection of the yellow and green boxes, represents the mean grain profitability. Finally, the top of the green boxes and the bottom of the yellow boxes represent "mean + two standard deviations" and "mean - two standard deviations", respectively. For Dyer and Sheridan Counties, the minimum profitability values are higher than "mean - two standard deviations" suggesting the skewed nature of the estimated profitability distribution. 

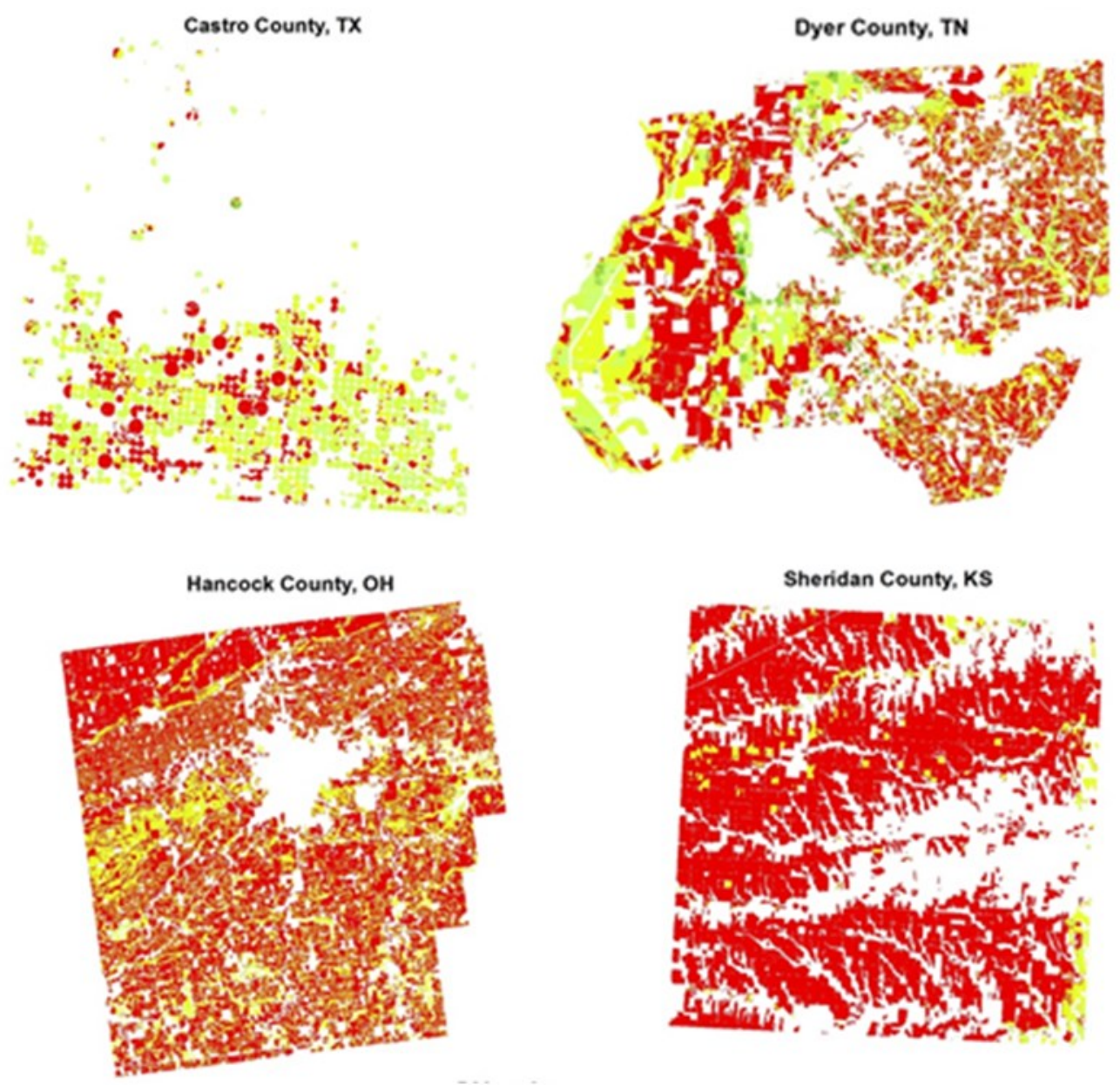

5 Year Average Profit (\$/ac)

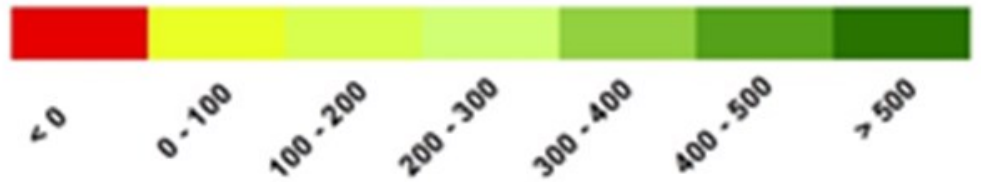

Fig 4 Five-year average profitability of field crop production in each of the four study counties. 


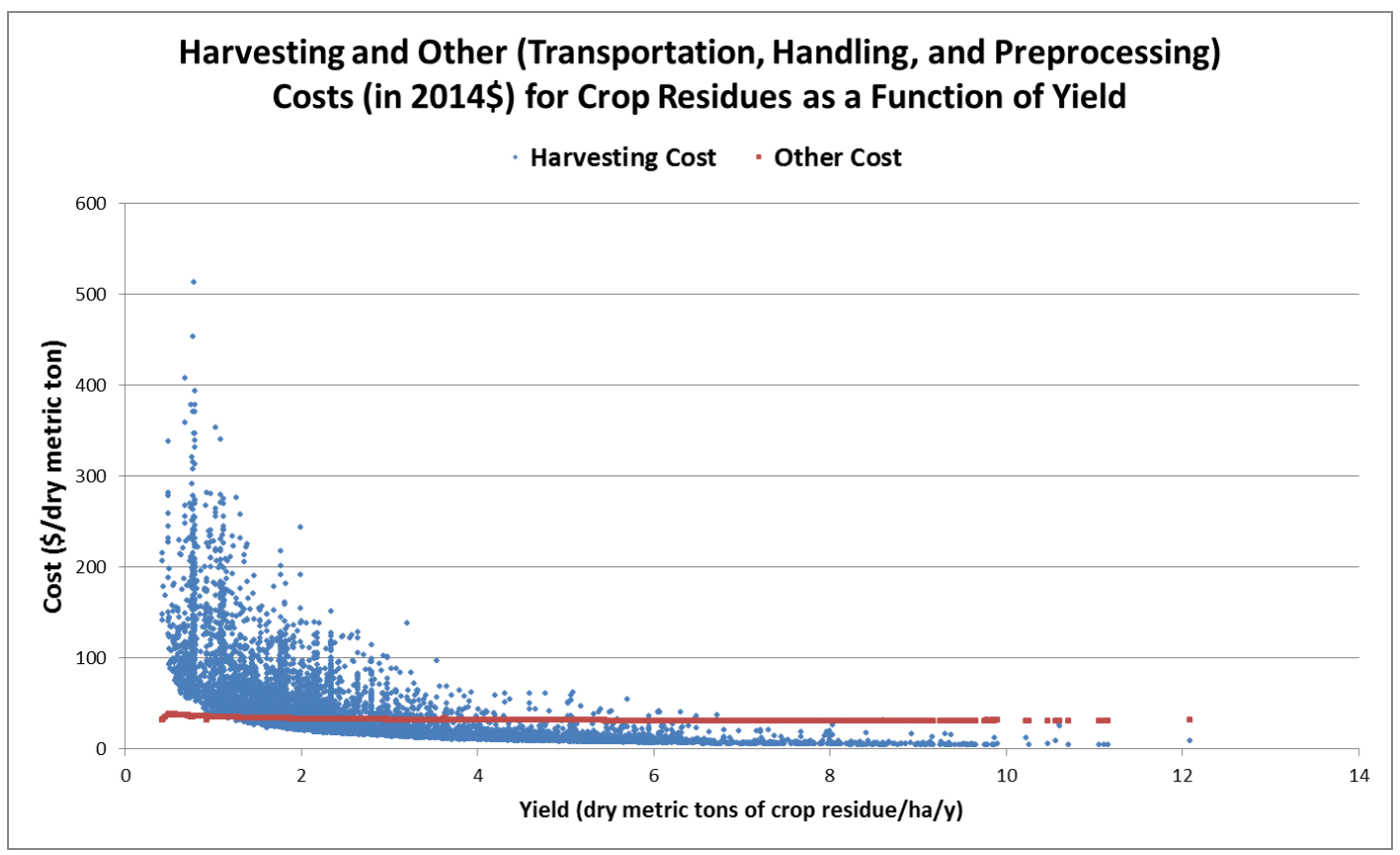

Fig 5 Total cost (sum of harvesting, handling, transportation, and preprocessing costs and not including payments to farmers) as a function of biomass or energy crop yield (at $2014 \$$ ). 


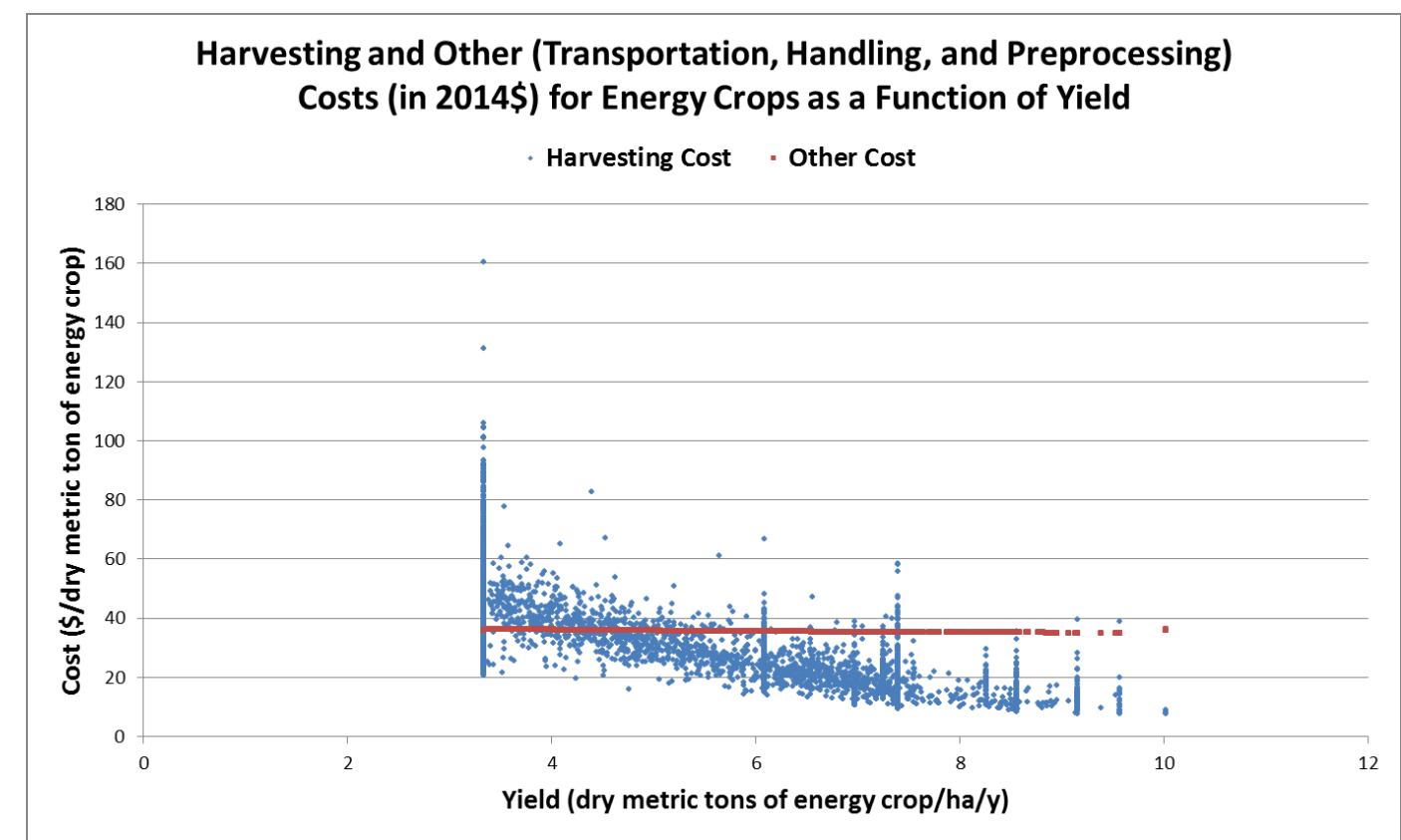

Fig 6 Total cost (sum of harvesting, handling, transportation, and preprocessing costs and not including payments to farmers) as a function of biomass or energy crop yield (at $2014 \$$ ). 


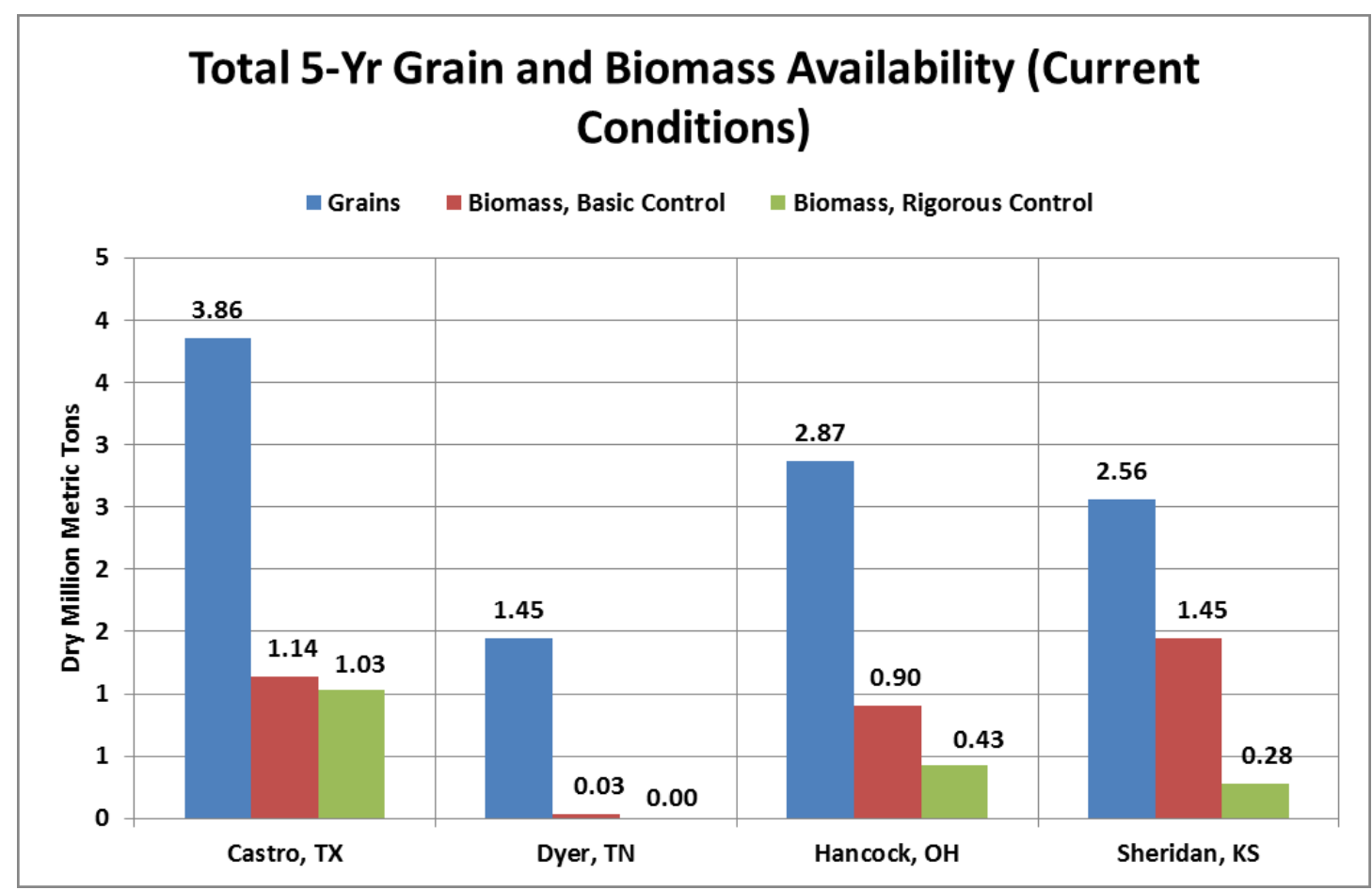

Fig 7 Availability of grains and biomass from the four counties analyzed between 2010 and 2014.

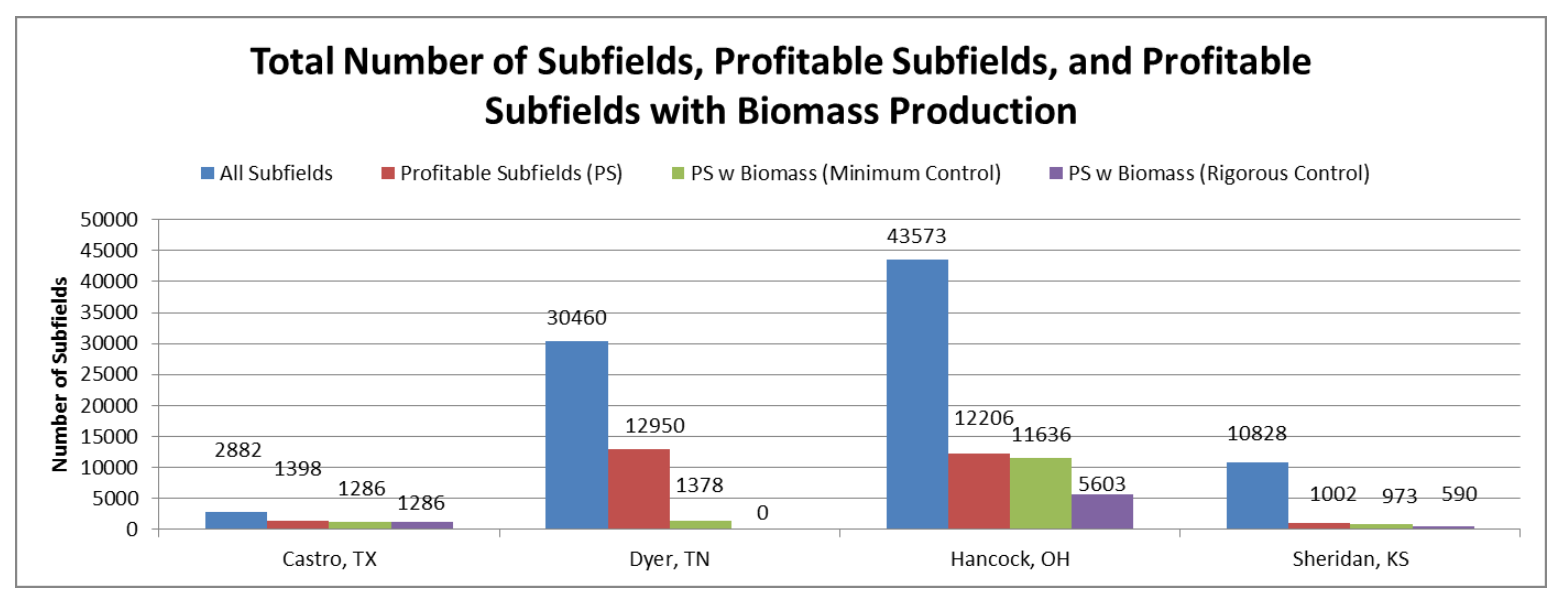

Fig 8 Number of profitable subfields and profitable subfields producing biomass within each county. 


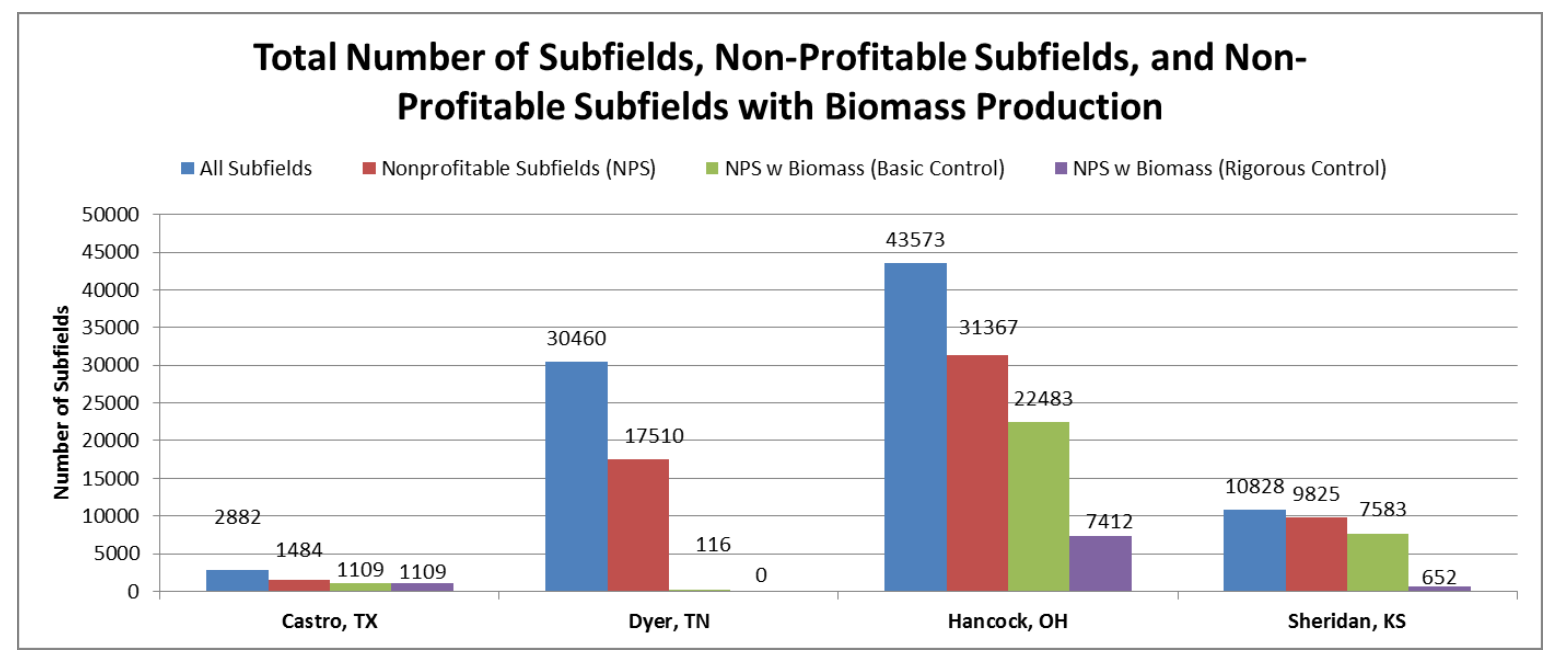

Fig 9 Number of non-profitable subfields and non-profitable subfields producing biomass within each county.

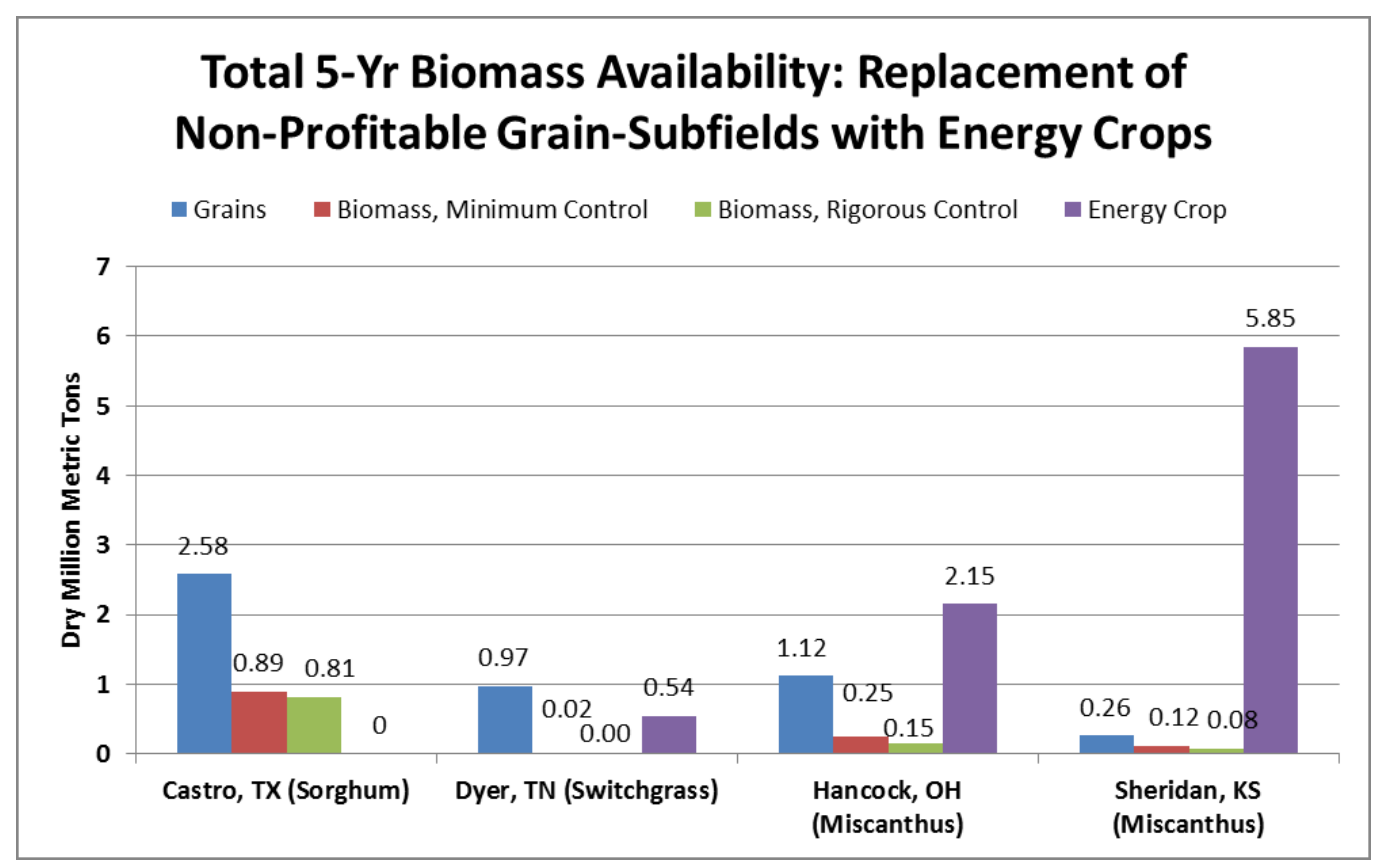

Fig 10 Availability of grains and total biomass from the four counties analyzed between 2010 and 2014 after replacing non-profitable subfields with energy crops. 


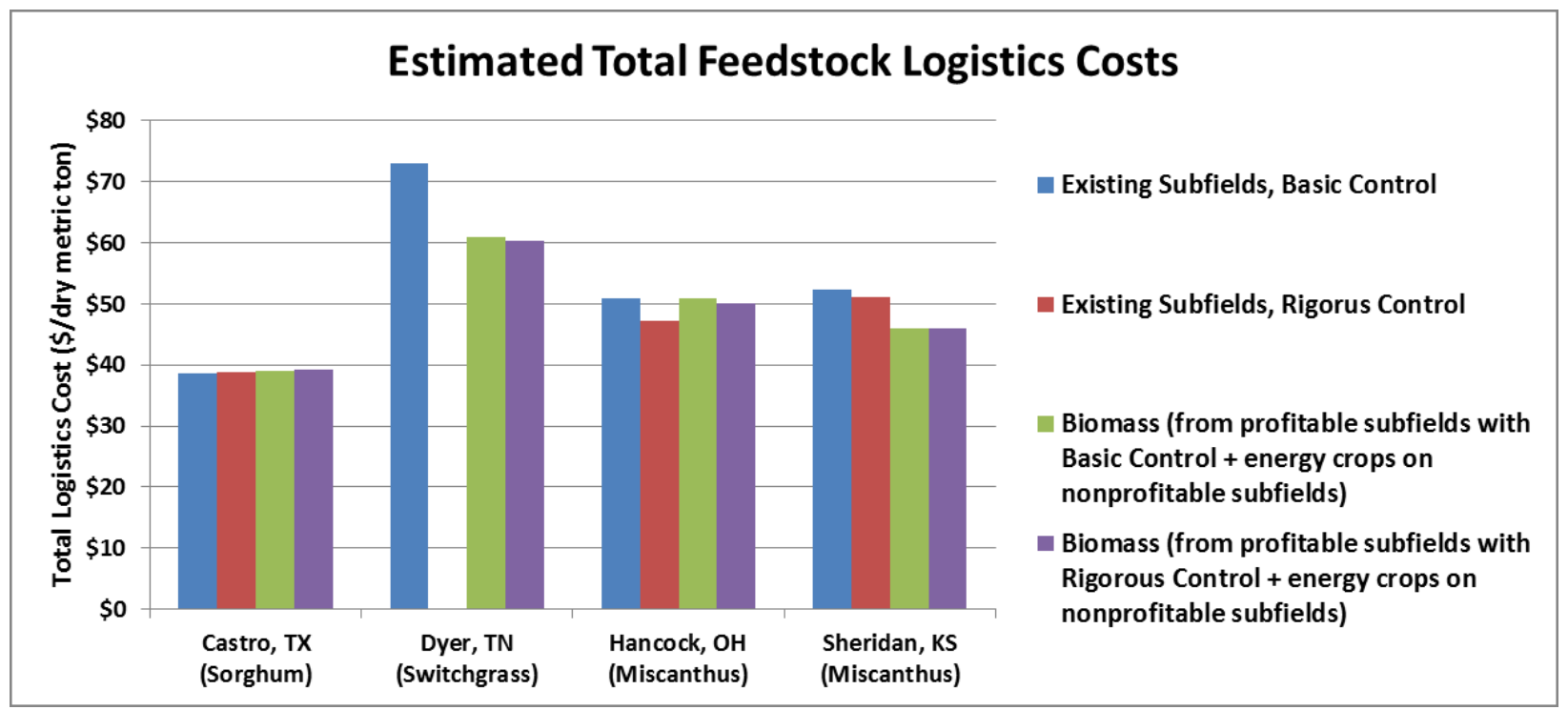

Fig 11 Estimated total feedstock costs in 2014\$ for the scenarios considered in this study.

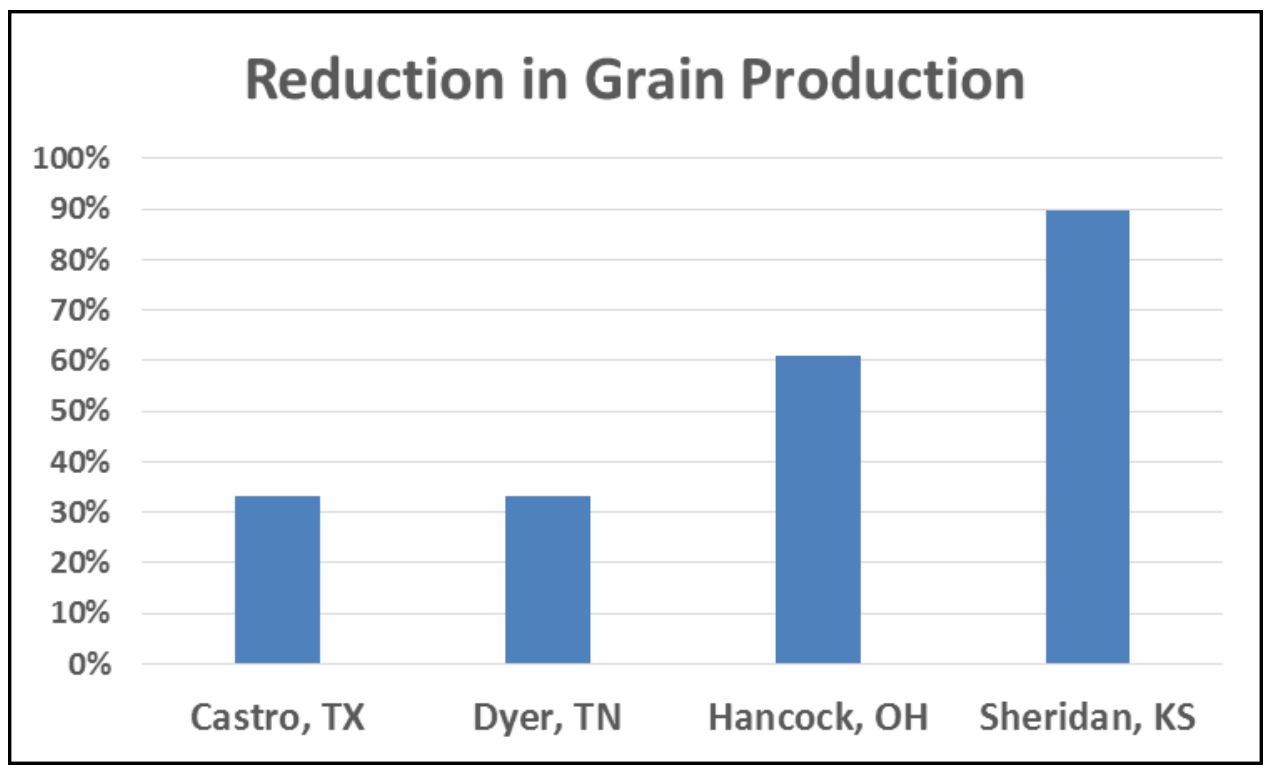

Fig 12 Reduction in grain production as a result of replacing non-profitable grain subfields with energy crops. 

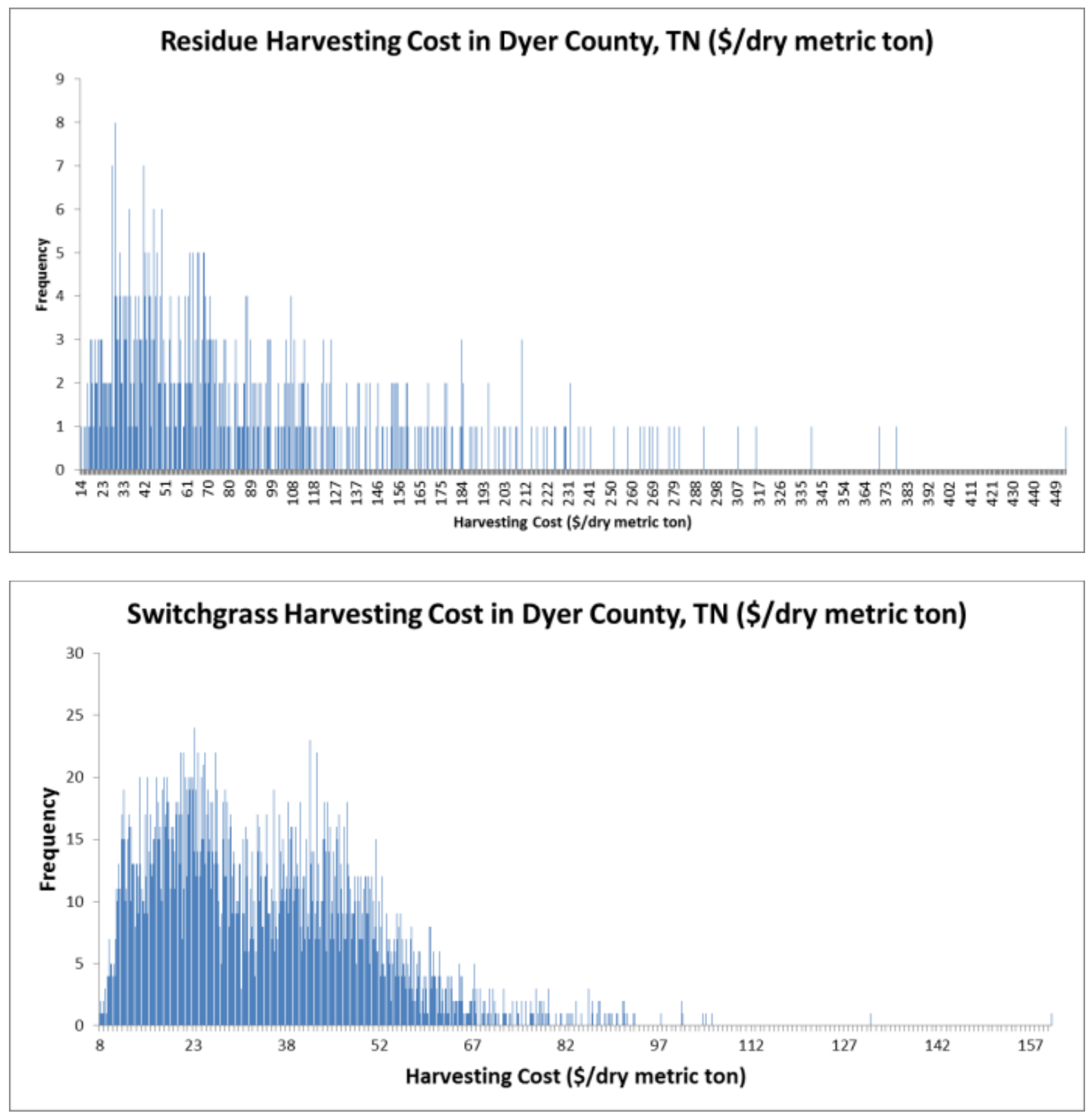

Fig 13 Histograms of cost for harvesting residues and energy crops on CLUs in Dyer County, TN. 

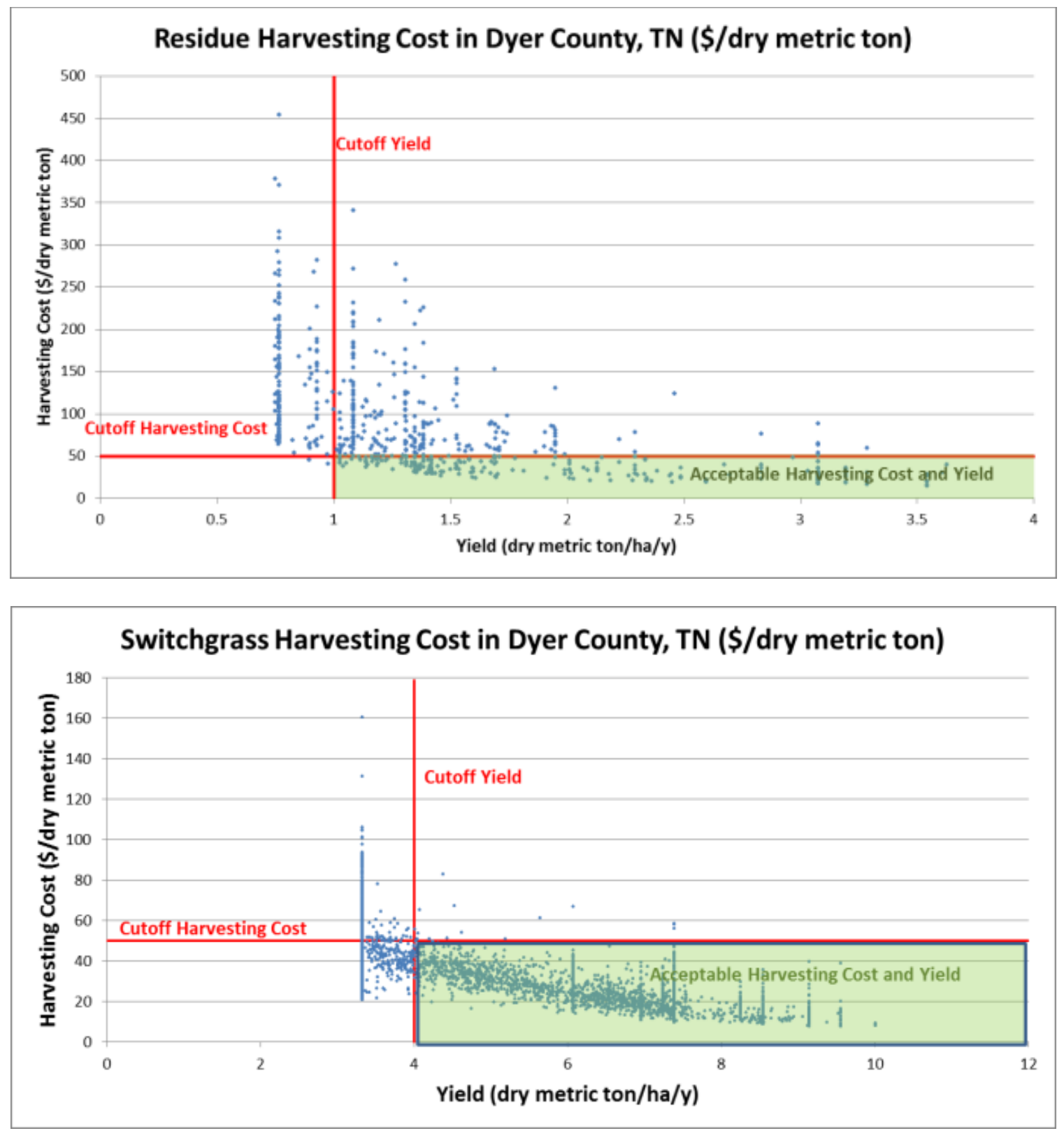

Fig 14 CLUs with acceptable harvesting cost and yields for residue and energy crop harvesting. 